\title{
Soft Sediment Deformation Structures in the Maastrichtian Patti Formation, Southern Bida Basin Nigeria: Implications for the Assessment of Endogenic Triggers in the Maastrichtian Sedimentary Record
}

\author{
Solomon Ojo Olabode \\ Department of Applied Geology, The Federal University of Technology, Akure, Nigeria \\ Email:solobode@futa.edu.ng,bodesolomon@yahoo.com
}

Received 1 April 2016; accepted 24 June 2016; published 27 June 2016

Copyright (C) 2016 by author and Scientific Research Publishing Inc. This work is licensed under the Creative Commons Attribution International License (CC BY). http://creativecommons.org/licenses/by/4.0/ (c) (7) Open Access

\begin{abstract}
Detailed fieldwork carried out in the southern part of Bida Basin, Nigeria, allowed the documentation of soft sediment deformation structures (SSDS) in the Maastrichtian Patti Formation. The aim of this study is to examine the sedimentary successions, describe and analyse these deformation features, discuss their deformation mechanisms and potential triggers. The Maastrichtian Patti Formation is composed of lithofacies interpreted to have been deposited in tidal and fluvial sedimentary environments. Soft sediment deformation structures recognised in the tidal sediments were clastic dykes, load cast, isolated sand balls, dish-and-pillar structures, convolute lamination, diapiric structures and recumbent folds. Severely deformed cross beds, ring structures, associated sand balls, normal folds and recumbent folds were identified in the fluvial sediments. SSDS recognised were interpreted to have been caused by effects of liquefaction and fluidization. Field observations, facies analysis and morphology of the SSDS indicate that there are relationship between the depositional environments and SSDS. Endogenic processes are considered as the trigger agents and they are represented by rapid sedimentation and overloading, impact of breaking waves, pressure fluctuations caused by turbulent water flow, cyclic stress and current generated by storm waves and changes in water table. The present study did not identify exogenic processes as trigger agent. The occurrence of SSDS in southern Bida Basin strongly favoured a non-tectonic origin but a clear relationship high energy processes in tidal and fluvial depositional environments.
\end{abstract}

\section{Keywords}

Soft Sediment Deformation Structure, Bida Basin, Patti Formation, Tidal/Fluvial Sediments, 


\section{Fluidization and Liquefaction}

\section{Introduction}

The geologic history of the Southern Bida Basin, located in the central part of Nigeria favoured the presence of well-exposed different types of soft-sediment deformation structures (SSDS). These SSDS occur in the Maastrichtian Patti Formation, which can be recognised in newly exposed sections in the southern part of the basin. These structures are located in exposures close to the towns and villages such as Ozi, Gegubeki, Gerinya, Achabo, Ahoko and Gadabiu.

Soft sediment deformations include different types of deformations related to a drastic decrease in shear resistance in water-saturated and unconsolidated sediments. These structures are related to liquefaction and fluidization processes, which can develop in ancient and modern sedimentary environments. The past few decades have received significant attention in the studying and understanding of soft-sediment deformations. Research publications on this subject matter have revealed that the main processes (liquefaction and fluidization) causing the deformation allow a temporary change from solid-like to viscous-like behaviour in the sediments [1]-[3]. Soft sediment deformation structures may be induced by a number of factors, which include: 1) gravitationally unstable conditions; 2) slope instability; 3) overloading and unequal loading conditions; 4) wave-induced cyclical stresses; 5) fluid flows; 6) sudden changes in groundwater level and 7) earthquakes. SSDS have been recognised and interpreted from different sedimentary environments [4]-[7] but some characteristic features are useful to identifying the origin of the deformations [2].

Maastrichtian sedimentary successions in the intracratonic Bida Basin are wide spread in Central Nigeria, but there is no study directly addressing the issue of soft sediment deformation in this basin, especially the southern part. The stratigraphy and paleo-environmental studies of Maastrichtian Patti Formation in the southern part of Bida Basin have been described by the following authors: [8]-[10]. The fluvial to shallow marine deposits of the Patti Formation bear horizons of soft sediment deformation structures which have not been previously studied.

The principal goal of this paper is to examine the sedimentary successions in the area of study with a view to identify, to describe and to analyse beds containing soft sediment deformation structures in the different localities where they have been identified. The analyses shall focus on the detail description of the morphology of various types of soft-sediment deformation structures and infer the genetical relationship between the deformations and the dynamics of the depositional environments. In addition, it is intended that the trigger mechanisms responsible for the formation of the SSDS shall be elucidated.

\section{Geological Setting}

Bida Basin is a NW-SE trending intracratonic basin extending from Kotangora (northern Nigeria) to Lokoja in the central part of Nigeria (Figure 1). It forms a shallow linear depression with sedimentary thickness that varies from $2 \mathrm{~km}$ to $3.5 \mathrm{~km}$ and occupies a gently downwarped trough [11] [12]. The origin of the basin is closely related to Santonian tectonic crustal movements, which affected the Benue Basin and SE Nigeria. A post-Santonian shallow cratonic sag and pull-apart origin was proposed by [13]. Geophysical studies have shown that Bida Basin is bounded by a NW-SE trending system of linear faults and central positive anomalies flanked by negative anomalies [11]. This structural pattern is consistent with rift related structures as observed in the adjacent Benue Trough.

The stratigraphy of the Bida Basin was previously referred to as Lokoja Series [14]. This was followed by the work of [15] who referred to these sedimentary successions as Nupe Group. [16] divided the sedimentary successions into northern Bida and southern Bida Basins. The southern Bida Basin comprises of three formations which are Campanian to Maastrichtian in age: Lokoja Formation, Patti Formation and Agbaja Ironstone [9] [10]. These formations have their lateral equivalents in the northern Bida Basin which are Bida Formation, Sakpe Ironstone, Enagi Siltstone and Batati Ironstone respectively (Figure 2).

In the southern Bida Basin, the Lokoja Formation unconformably overlies the Precambrian crystalline basement complex rocks. The Formation comprises false bedded conglomerates, cross bedded pebbly and coarse grained sandstones, siltstones and claystones. These different lithologic units were interpreted as products of 

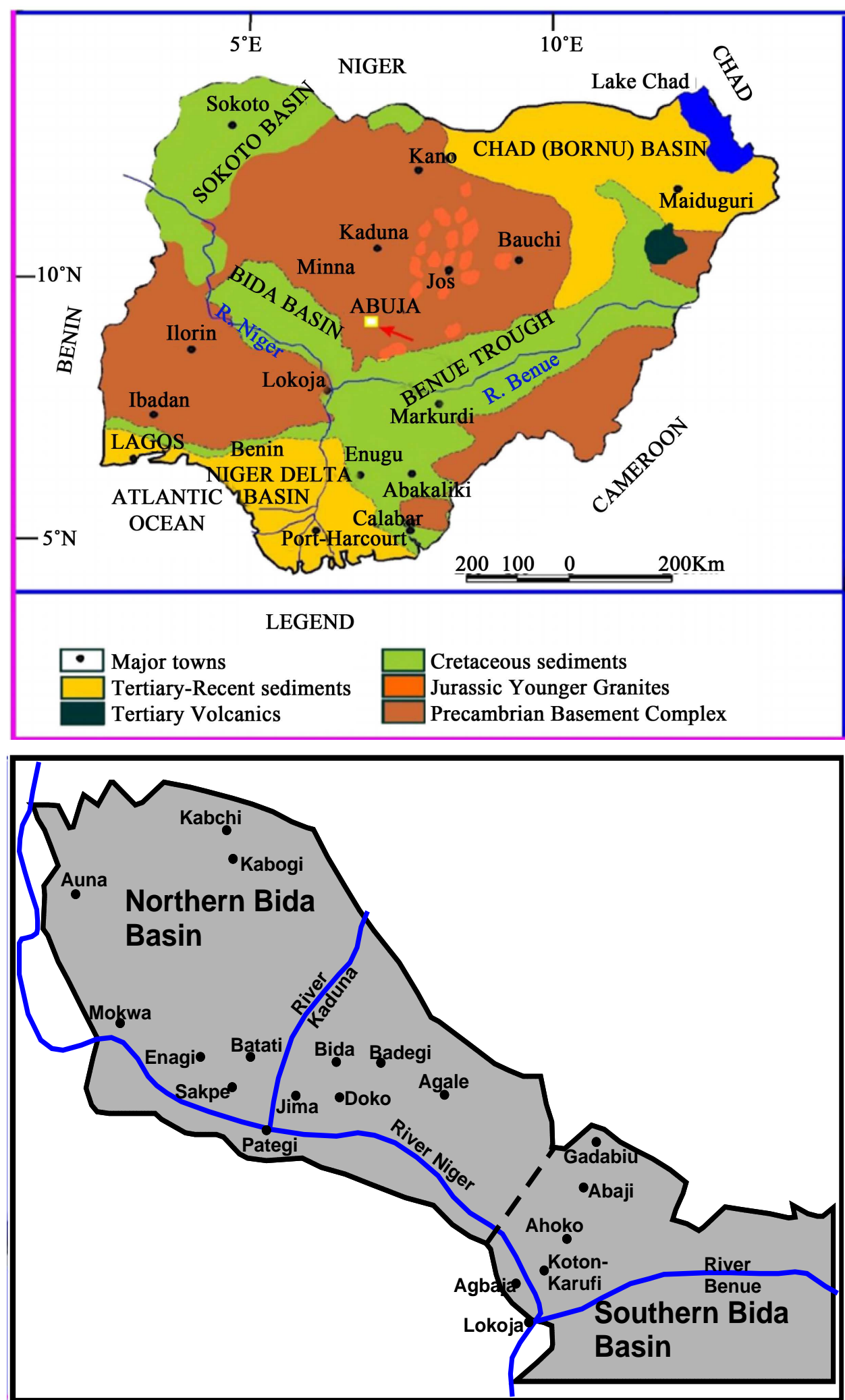

Figure 1. Map of Nigeria showing the NE-SW trending Mid-Niger/Bida Basin. The second map shows the expanded part of the basin and the boundary between northern and southern parts (Modified from [9]). 


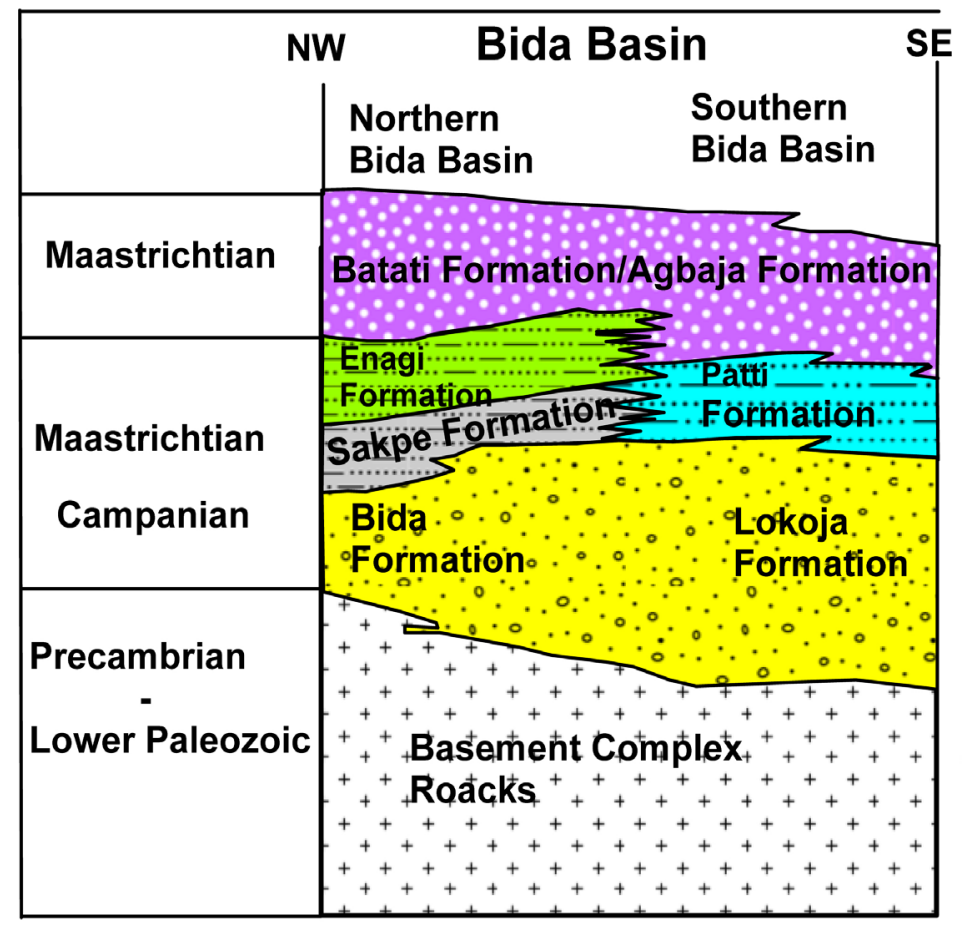

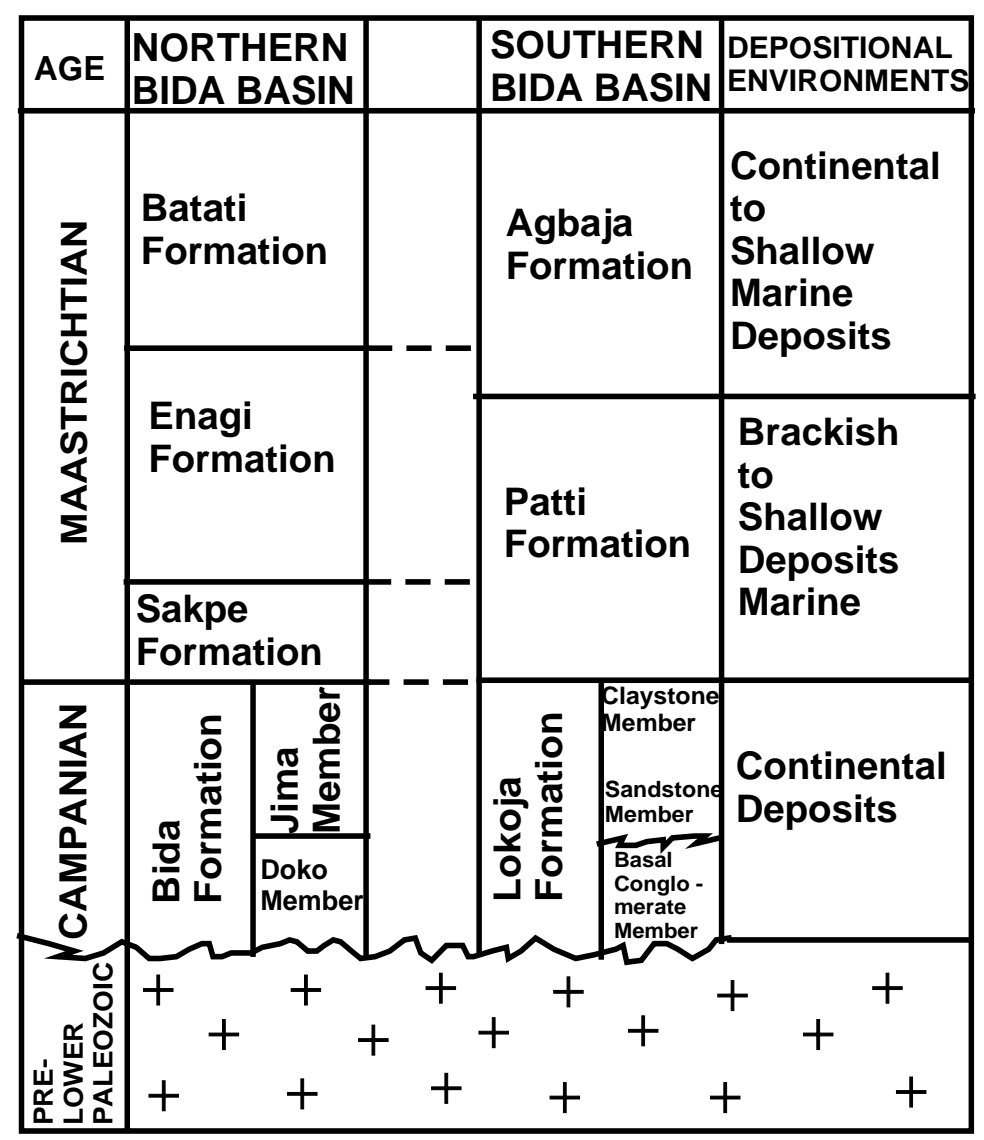

Figure 2. Stratigraphy of the NW-SE trending Bida Basin. Stratigraphic relationships and depositional environments in the northwestern and southeastern parts are highlighted (Modified from [10]). 
braided fluvial depositional environments, flood plain and overbank deposits [10]. The Lokoja Formation is overlain by Patti Formation, which consists of sandstones, siltstones, claystones and shales with interbeds of ironstones. This Formation was interpreted as products of quiet water deposition in shallow marine environment. Marginal marine environment has also been suggested for the Formation based on the occurrence of arenaceous species of foraminifera (Ammobaculites, Milliamina, Trochamina and Textularia) recovered from the shales [9] [17]. The Agbaja Formation consists of sandstones and claystone interbeds with oolitic and concretionary massive ironstone beds. The ironstone forms the cap in most topographic highs in the area and consisting of brown, yellow to white goethic and kaolinitic oolites in a yellow limonitic silty matrix. [18] interpreted the sandstones and claystones lithofacies as products of abandoned channels and overbank deposits influenced by marine reworking to form the massive and concretionary oolitic ironstones. Evidences of marine transgression have also been documented in the Agbaja Ironstone [8] [19].

\section{Sedimentology}

Detailed description of facies associations and depositional environments of the Patti Formation has been carried out by some authors, notably; [9] [10] [14]-[16] [20]. These later authors showed that the Maastrichtian Patti Formation is characterised by the following facies associations: 1) shoreface 2) tidal channels 3) tidal marsh to coastal swamp 4) fluvial channels and 5) non-marine swamp/overbank facies. Study carried out in the present fieldwork (Figure 3) revealed the occurrence of sediment deposited in tidal and fluvial environments (Figures 4-6).

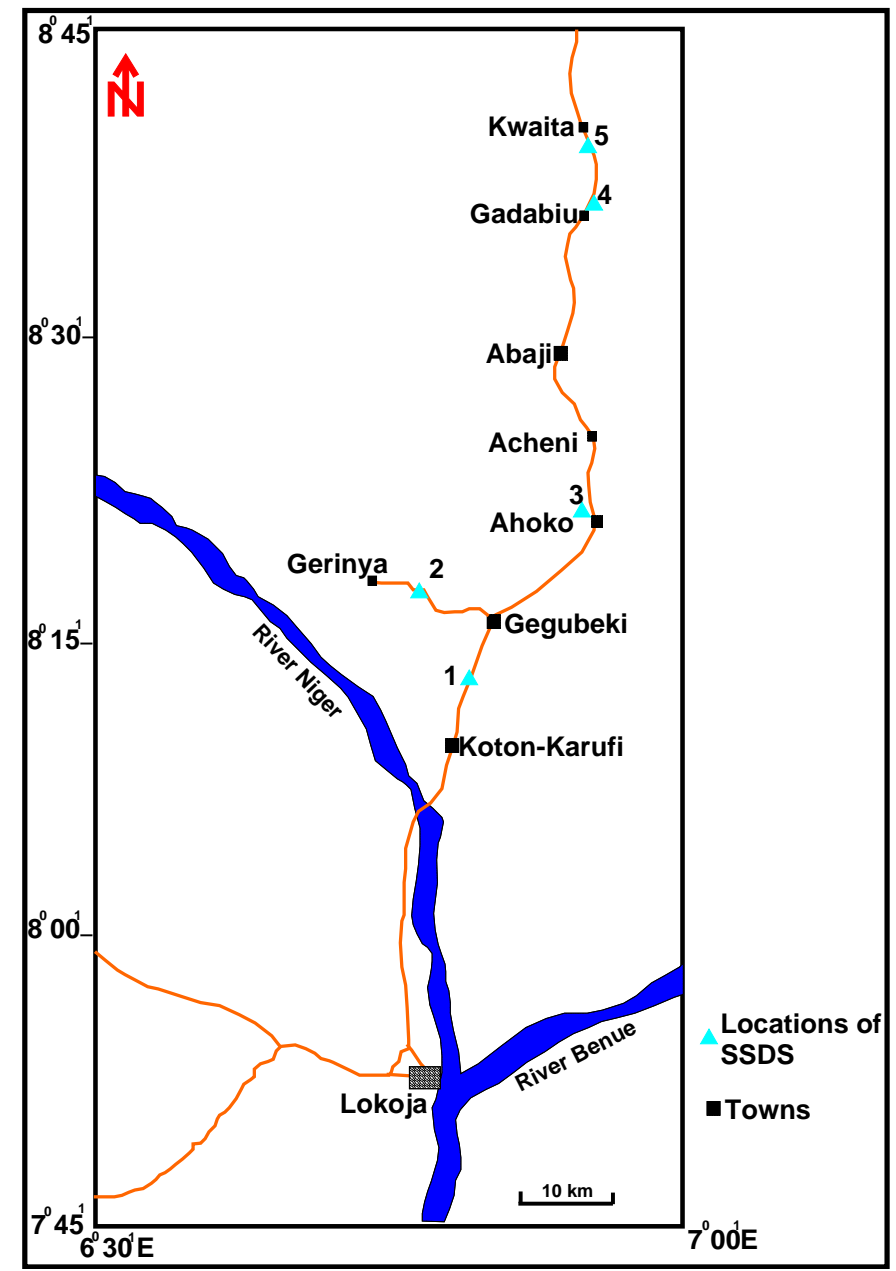

Figure 3. Map showing the location of sedimentary exposures where soft sediment deformation structures (SSDS) were recognised. 


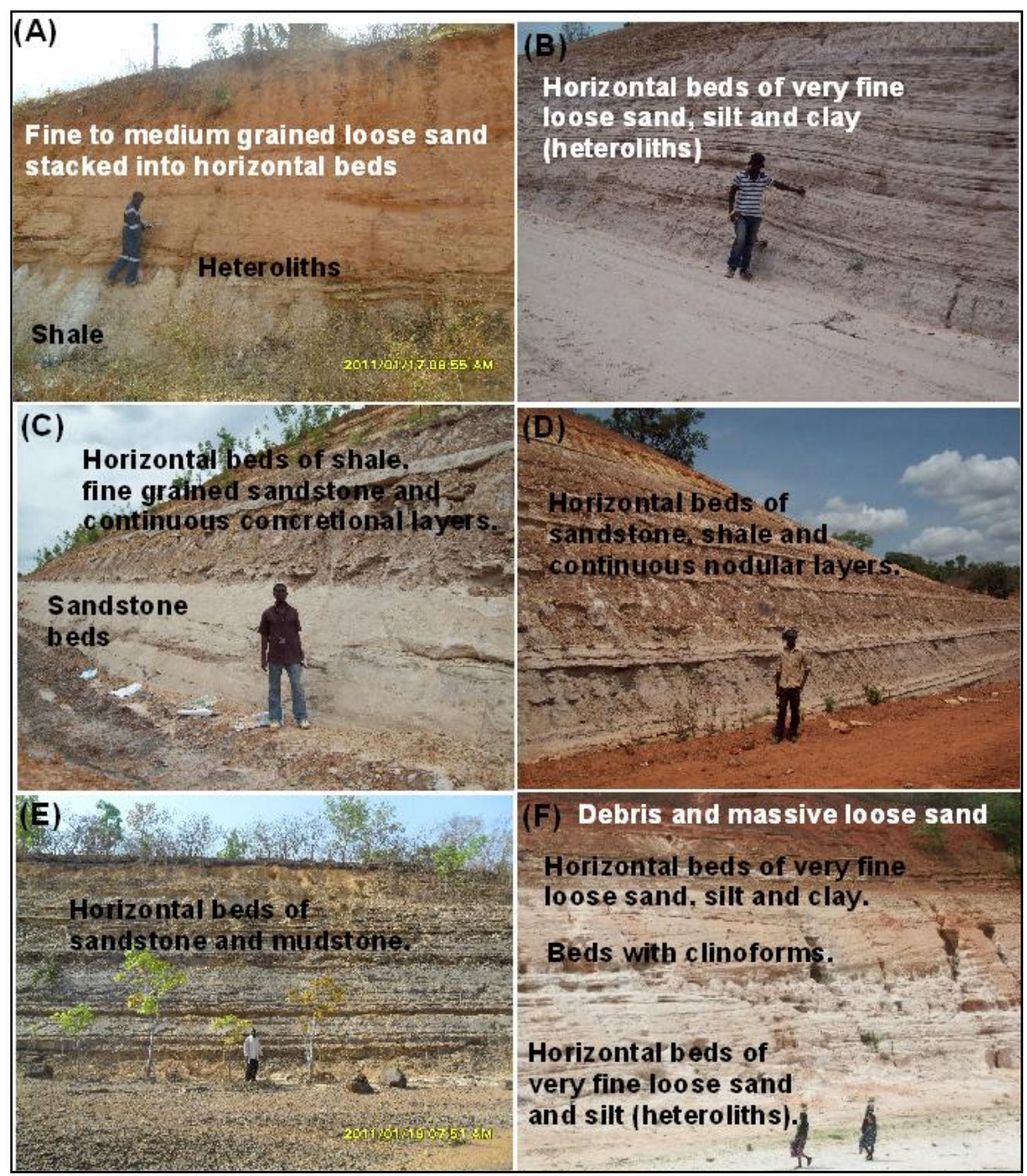

Figure 4. Field photographs showing different types of facies deposited in tidal depositional environments. (A) Three different lithofacies (shale, heteroliths, loose sand) arranged into horizontal beds are recognised. SSDS are present in the boundary between the shale and overlying lithofacies. (B) Heterolithic facies of loose sand, silt and clay. SSDS are also associated with the facies. (C) Thick sandstone beds overlie by horizontal beds of shale and sandstone containing concretions. SSDS are also present in the facies. (D) Continuous parallel beds of shale, sandstone and concretions. (E) Horizontal beds of sandstone and mudstone containing SSDS. (F) Heterolithic facies of loose sand, silt and clay capped by debris deposits. Clinoforms are recognised in the middle section. SSDS are also present in the exposure.

Heterolithic facies within the formation is composed of moderate to well sorted, gray siltstone, very fine grained sandstone and clay. Thickness ranges from $3 \mathrm{~m}$ to $10 \mathrm{~m}$. Based on outcrop studies, the facies is exposed 

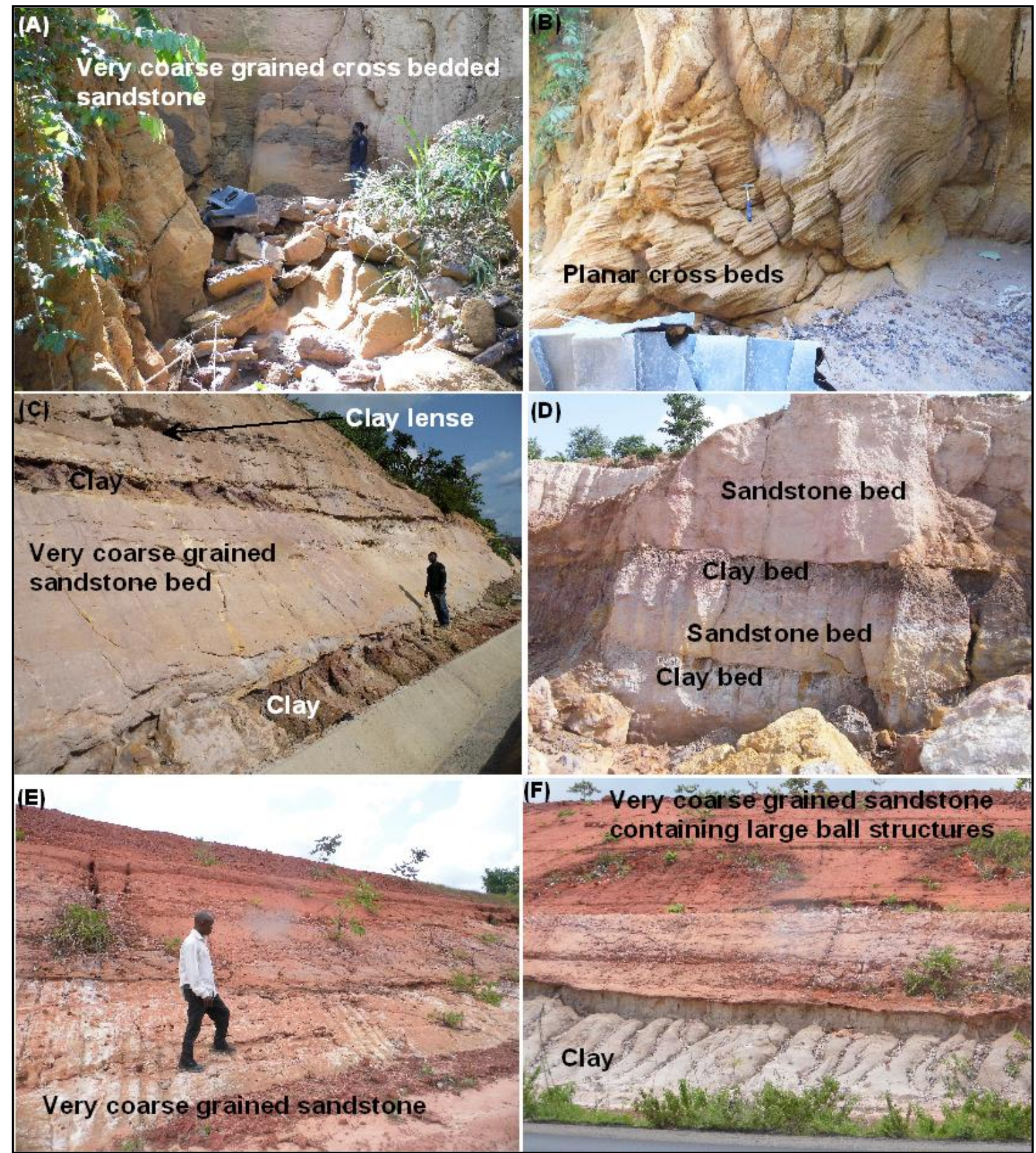

Figure 5. Field photographs showing different types of facies deposited in fluvial depositional environments. (A) Very coarse grained cross bedded sandstone characterised by planar cross beddings and horizontal beds. SSDS are recognised within the facies. (B) Close-up view of planar cross beddings in the loser section of A. (C) Fluvial channel and overbank deposits comprising of clay with lense and wedge geometries and very coarse grained cross bedded sandstone. (D) Close-up view showing clay and sandstone beds. (E) Thick beds of very coarse grained sandstone containing SSDS. (F) Vertical facies change from clay to very coarse grained sandstone representing fluvial plain and fluvial channel deposits respectively.

at different road sections and is correlative. Sedimentary structures include very thin ( $<1 \mathrm{~mm})$, thin $(1-2 \mathrm{~mm})$ and thick $(2-10 \mathrm{~mm})$ parallel laminae. This structure was recognised in all the lithologic units present within the heterolithic facies. Repetitive thickening- and thinning upward lamination sets are present characterised by laminated couplets. Rippled, reactivation and erosional surfaces are recognised in the lithofacies (Figure 4). 

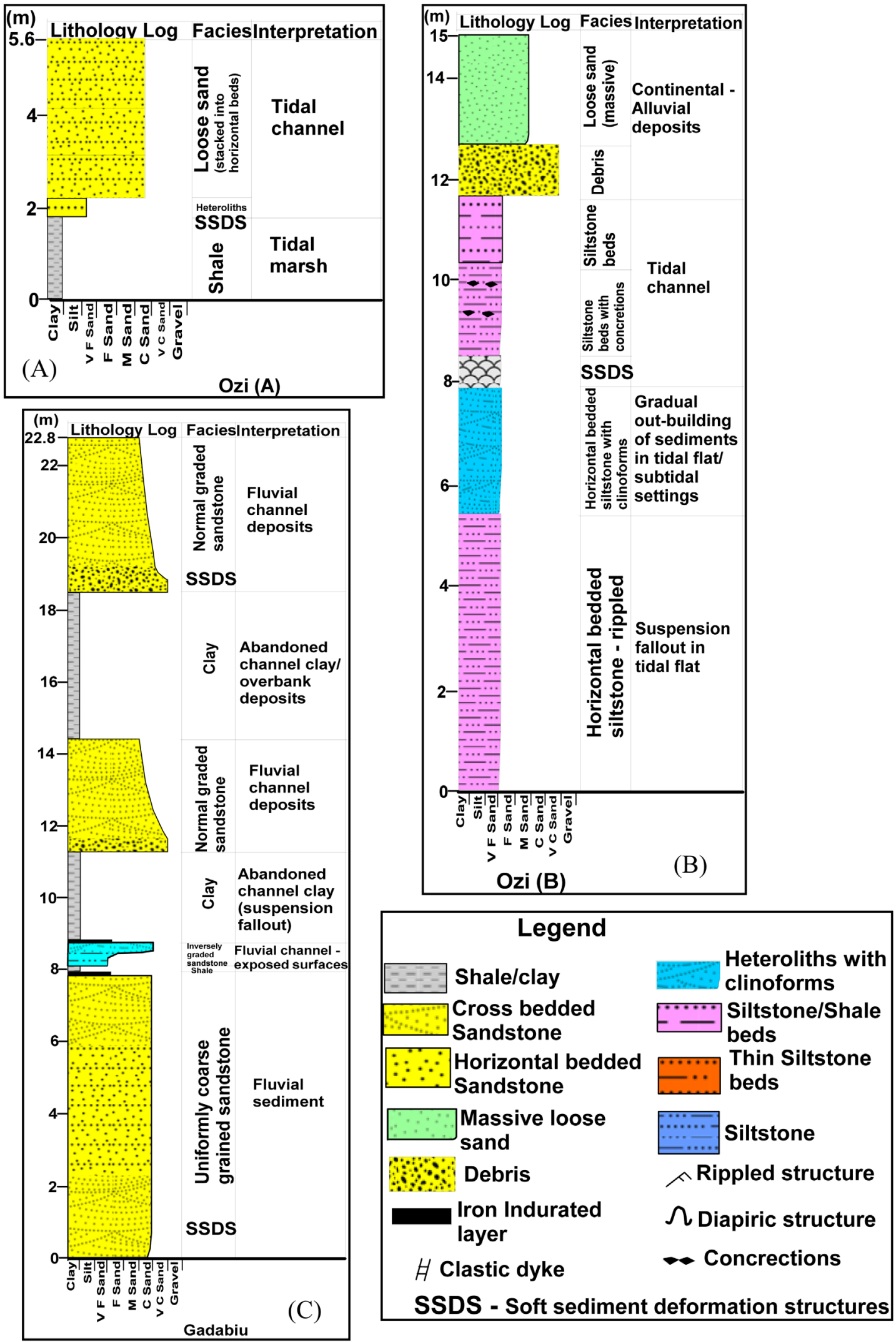

(a) 

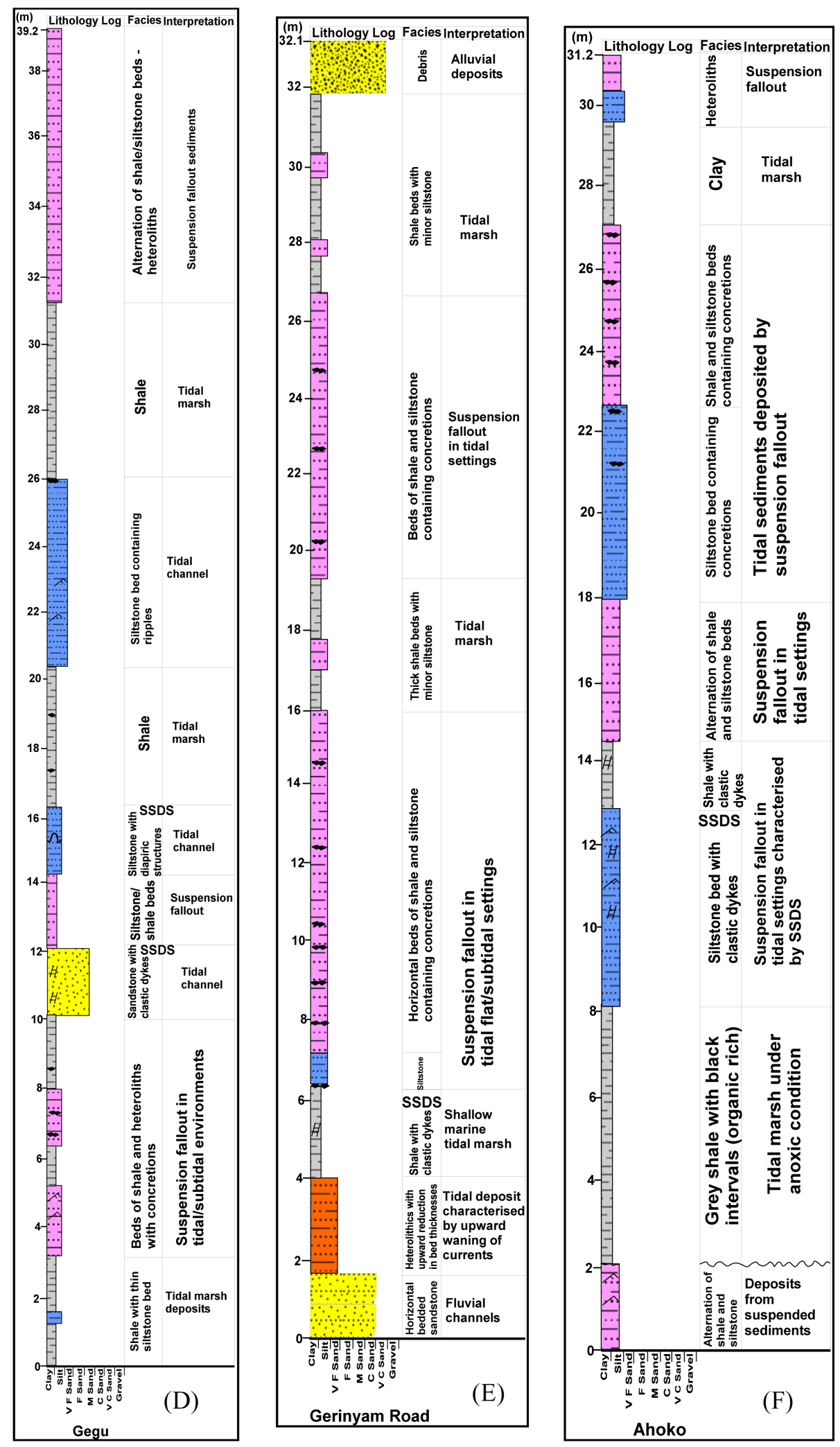

(b)

Figure 6. (a) Graphic lithologic log showing the lithology, facies and interpretation for the sedimentary exposures logged in the different locations. Interval containing SSDS are shown in all the logs. (b) Continuation of graphic lithologic log. 
The heterolithic facies is interpreted as deposits of alternation of flood-ebb tidal currents and intervening slack-water suspension fallout in lower tidal flat or subtidal coastline settings. Tidal deposits are typically represented by heterolithic facies characterised by rhythmic interbedding of thin very fine grained sandstone, siltstone and clay layers. Exclusive indicators of tidal deposits are the occurrence of reactivation surfaces, mud couplets and lamination bundles that was recognised in the facies. Soft-sediment deformation structures were recognized in the facies associations of [10] and in the heterolithic facies.

Fieldwork carried out in the area of study also revealed the occurrence of fluvial sandstone facies in the road sections and quarries. This facies are vertically stacked into very coarse to medium grained cross bedded sands/sandstone bodies, which are separated by layers of clay and very thin shale. Four distinct layers of very coarse-medium grained cross bedded sands/sandstone was delineated (Figure 6(C)).

1) Uniformly Coarse Grained Sandstone: This is the lowermost lithofacies delineated in the area. The base of this layer was not exposed, vertically it is uniformly coarse grained, forming non-cyclic stacked storey of $7.9 \mathrm{~m}$ thickness (Figure 5(A) and Figure 5(B), Figure 6(C)). The sandstone body is weakly consolidated, reddish brown in colour, grains are angular to sub-angular, poorly sorted and kaolinitic. Internally the lithofacies is either horizontal or cross bedded. Horizontal bedded sandstone occur in the middle part and constitute about 50\% of the sedimentary succession, while cross bedded sandstone occur at the upper part forming the remaining $50 \%$. Cross beds are planar, unidirectional and composed of layers of coarse grained sandstones with set thickness varying from $1 \mathrm{~cm}$ to $10 \mathrm{~cm}$ and foreset laminae range from $0.2 \mathrm{~cm}$ to $0.4 \mathrm{~cm}$. The angle of foreset inclination is variable ranging from $1^{\circ}$ to $35^{\circ}$ (Figure 5(A) and Figure 5(B)). Cross beddings reveal east-southerly current directions with paleocurrent values varying from $146^{\circ}$ to $165^{\circ}$. This lithofacies is capped by indurated $3 \mathrm{~cm}$ thick siltstone layer and contain soft sediment deformation structures. Shale layer separated this lithofacies from the overlying sandstone (Figure 6(C)).

2) Inversely Graded Sandstone: This is the second sandstone layer identified in the area. Measured total thickness is $54 \mathrm{~cm}$ and can be divided into two layers. The lower $34 \mathrm{~cm}$ and upper $20 \mathrm{~cm}$ exhibited horizontal and cross beddings respectively. Grains within horizontal beds are predominantly fine-medium, exhibiting alternation of colours varying from light brown to light grey and reddish brown. Grains within cross beddings are predominantly coarse and reddish brown without alternation of colours. Generally, grains are poorly sorted, arkosic and capped by $5 \mathrm{~cm}$ thick of indurated siltstone. Clay layer occur as the overlying lithofacies and separate it from the next sandstone layer. Soft sediment deformation structures were not identified in this lithofacies.

3) Normal Graded Cross Bedded Sandstone: Two layers of normal graded sandstone separated by clay were delineated. Measured thicknesses of the lower and upper layer are $3.1 \mathrm{~m}$ and $4.1 \mathrm{~m}$ respectively. These sandstone bodies are characterised by variable colours-milky white, brown and purple. They are gravelly at the base very coarse grained containing quartz pebbles while the top is medium grained. Generally, they poorly sorted; grains are angular to sub-angular and contain weathered feldspars. The lower layer has an irregular, sharp, indurated erosional boundary with thickness varying from $1 \mathrm{~cm}$ to $2 \mathrm{~cm}$. Several wedge shape and clay filled channels are present within the lithofacies (Figure 5(C) and Figure 5(D)). The upper layer is also characterised by several channels containing multiple lensoid sandstone and clay fills (Figure 5(D)). Soft sediment deformation structure was identified in this upper layer.

4) Mudstone: Shale and clay lithologic units were delineated at three distinct intervals in the studied sections, although within the identified sandstone bodies some clay units occur as channel fills. Shale is predominantly laminated, horizontal bedded and smooth. The colour is light grey and measured thickness for the shale overlying the lowermost sandstone body is $3 \mathrm{~cm}$. Clay bodies were delineated at two separate intervals in the studied section. The lower clay body is $2.5 \mathrm{~m}$ thick, light grey to fairly dark, fairly smooth and charcterised by sharp upper and lower boundaries. The upper clay body is $4.1 \mathrm{~m}$ thick, light grey to purple with stains of reddish brown and fairly dark. This clay body exhibit wedge geometry as it thins toward the southern end of the exposure (Figure 5(C) and Figure 5(D)).

Fluvial Facies Interpretation: The basal section of the exposure is interpreted to be of braided stream origin. This lower section comprises of cross and horizontal beddings, which correspond to lithofacies Sp and Sh of [21]. The occurrence of cross beddings indicates evidence of deposition by current. This was interpreted as deposits of linguoid, transverse bars and sand waves in the lower flow regime. [22] interpreted similar planar cross bedded sands as sandy bedforms that developed as a result of sand migration under lower flow regime conditions in low sinuosity braided stream. The characteristics of the horizontal bedded coarse grained sandstone suggest deposition by series of broad, shallow, poorly defined short-lived channels. Deposits of short-lived 
channels typically resemble sheet deposits, laminated sand sheets and sandy bedforms [22] [23]. The horizontal beds are key characteristics of deposition from suspended sediments. This probably resulted from extremely coarse grains of sediments deposited as traction loads during the waning of water current. This agrees with interpretation of the workers who explained that massive or crudely bedded coarse sand characterized by horizontal bedding were products of longitudinal bars, lag deposits and sieve deposits [21] [24]-[26]. The mudstone facies recognised in the studied section, which include shale and clay are interpreted to have been deposited under slow sedimentation rates from suspended sediments. These facies probably represents facies deposited in abandoned channels or flood plains.

\section{Soft-Sediment Deformation Structures}

It may be difficult to use accurate classification scheme for soft sediment deformations structures because of the following reasons: 1) they occur in different types of geometries and morphologies; and 2) the processes responsible for their formation can be categorized as purely autogenenic or allogenic or a combination of both. In the exposed sedimentary sections of Patti Formation nine different types of well exposed and easily recognised soft-sediment deformation structures were distinguished. Their recognition was based on size and morphological characteristics. These soft sediment deformation structures are clay/sand ball/ellipsoidal structures, load structures, clastic dykes, convolute lamination, diapiric structure, recumbent folds, dish and pillar structures, severely deformed cross beddings and ring structures. These structures can be grouped into ductile and brittle deformation structures [27] [28].

\subsection{Brittle Soft Sediment Deformation Structures}

\section{Clastic Dykes}

Clastic dykes occur within shale, sandstone and laminated very fine grained sandstone and siltstone lithologies (Figure 7). Dykes that occur within clay beds are limited by horizontal layers of iron concretions at the base and top. In the sandstone lithology the continuity of the dykes were obliterated by clay layers that confined the sandstone beds. The dykes generally terminate abruptly within the laminated very fine sandstone and siltstone (Figure 7).

This soft sediment deformation structure consists typically of sandstone filling linear fractures. Two categories recognised in the studied outcrops are: 1) very thin dykes that occur within sandstone and shale lithofacies; and 2) large dykes that occur within laminated very fine sandstone and siltstone lithofacies. The small dykes have widths in the millimeter scale and represented by vertical, inclined and slightly curved fissures. In vertical section they are straight and characterised by uniform size upward with a maximum thickness of $4.4 \mathrm{~m}$. They are confined within the lithofacies in which they occur and terminate abruptly both upward and downward at the boundaries of the lithofacies (Figure 7(A) and Figure 7(B)). In few cases, where sandstone beds are in association with the shale the dykes cut through them (Figure 7(C)). The dykes are straight and contain infills of uniform very fine grained sandstone and siltstone, which are different from the beds in which they are found. Locally, in few of the exposures dykes exhibit cross-cutting relationship (Figure 7(D)). Field observations revealed that in the shale the formation of iron concretions postdated the occurrence of the sandstone dykes. These iron concretions appear to have cut through the lithology and gently pushed the thin dykes to the western direction i.e. left side of the exposure.

The large sedimentary dykes occur as slightly inclined fissures within the laminated very fine sandstone and siltstone (heteroliths). They range in size from $20 \mathrm{~cm}$ to $30 \mathrm{~cm}$ in width and less than $70 \mathrm{~cm}$ in length (Figure 8). Only two were recognised in the exposures and they terminate both upward and downward within the lithofacies. They are filled with coarse grained uniform sand material, which is not the same with the host lithology. Clastic dykes recognised in the area of study are not in association with other types of soft sediment deformation structures, they occur independently. Similar structures have been described by [2] [27] [29].

Interpretation: Clastic dykes recognised in the area of study indicate that there was formation of open fissures resulting from various causes: hydro-fracturing, tension gashes and overloading. It should be noted that sandstone beds that contain the dykes occur between clay beds. Therefore, injection from the clay beds is unlikely. Hence, neptunian dykes and injection structures [27] may not be applicable in this case. The most possible explanation for the occurrence of the sandstone dykes within the sandstone beds is the formation of extensional fractures in cohesive sediments, which was later filled by fine grained sandstone [30]. This interpretation is 


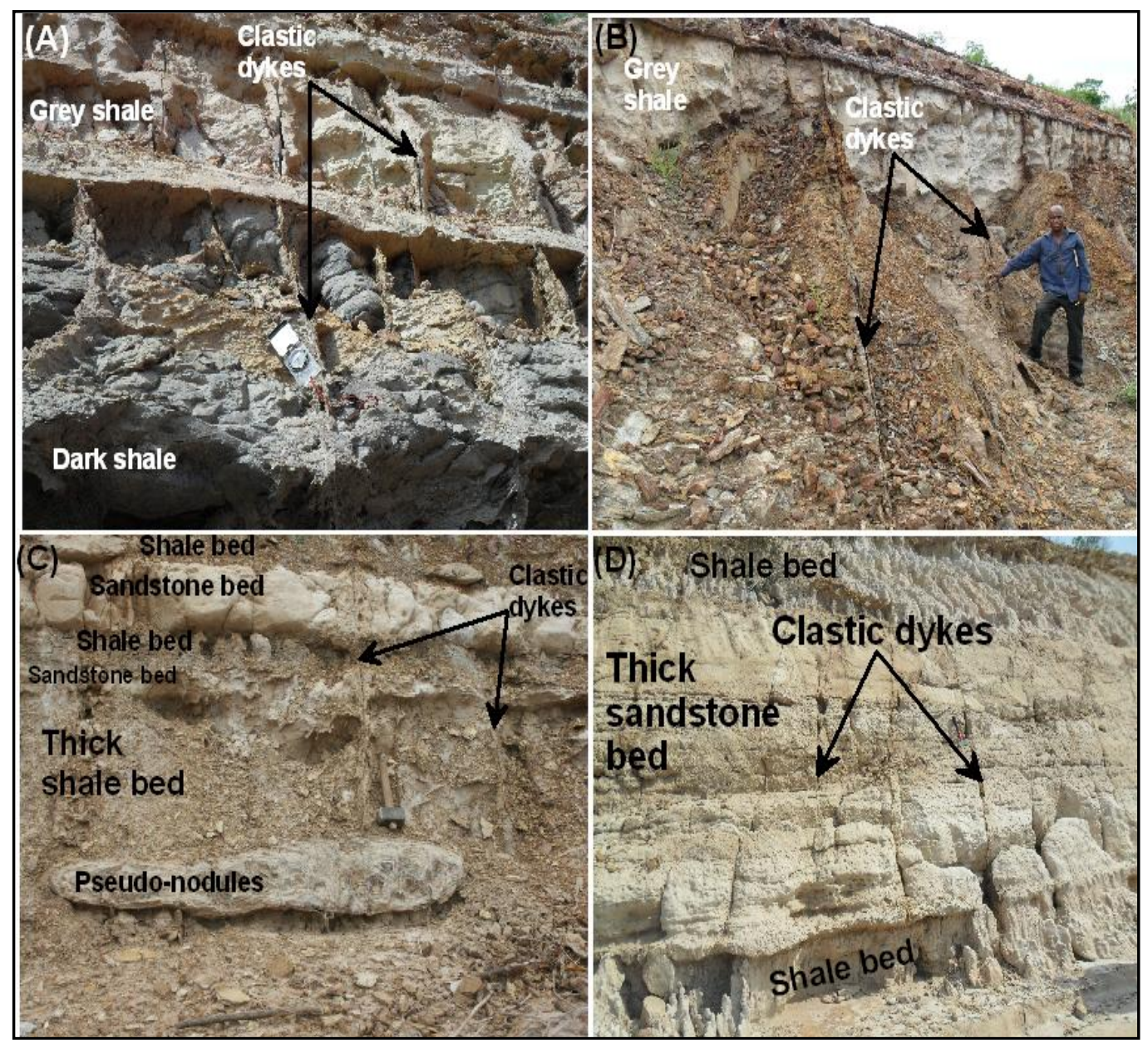

Figure 7. Occurrence of thin clastic dykes in different lithologic units as recognised in the studied sedimentary successions. (A) Clastic dykes in grey and dark shales, vertical continuity of the dykes are prevented by the occurrence of concretional layers. (B) Clastic dykes in this location are restricted to the shale lithology. (C) Clastic dykes in this location cut through different lithologic units (shale and sandstone). (D) In this location clastic dykes are present in the sandstone lithology only. The sandstone bed occurs within two shale beds.

unlikely to be applicable for the clay bed containing the clastic dyke. Clay beds that contain the sandstone dykes are underlained by sandstone beds, this indicate that injection structure is possible from the sandstone bed below. Therefore, this structure was generated by over-pressured water caused by a combination of fluidization process and hydraulic jacking [3] [27] [31]. Similar sedimentary clastic dykes have been described in the literature (e.g., [32] [33]), with suggested non-tectonic [34] and tectonic [35] and [36] origins.

\subsection{Ductile Soft Sediment Deformation Structures}

\subsubsection{Load Structures}

Two types of load structures were recognised in the study area; small scale load casts present in very fine grained sandstone and heterolithic facies and large scale load structure recognised in a channel.

1) Small Scale Load Casts

These structures consist typically of very fine to medium grained sandstone and siltstone filling sub-circular to circular features present in the underlying lithologies (Figures 9(A)-(C)). These structures can be symmetrical to asymmetrical and irregular. They are represented by bulbous downward projected drops of fine to medium grained sandstone that have sunk downward into the underneath deposited sandstone, siltstone and clay/shale. Their height ranges from $4.5 \mathrm{~cm}$ to $8 \mathrm{~cm}$ and their width from $5 \mathrm{~cm}$ to $11 \mathrm{~cm}$. The first two (Figure 9(A) and 

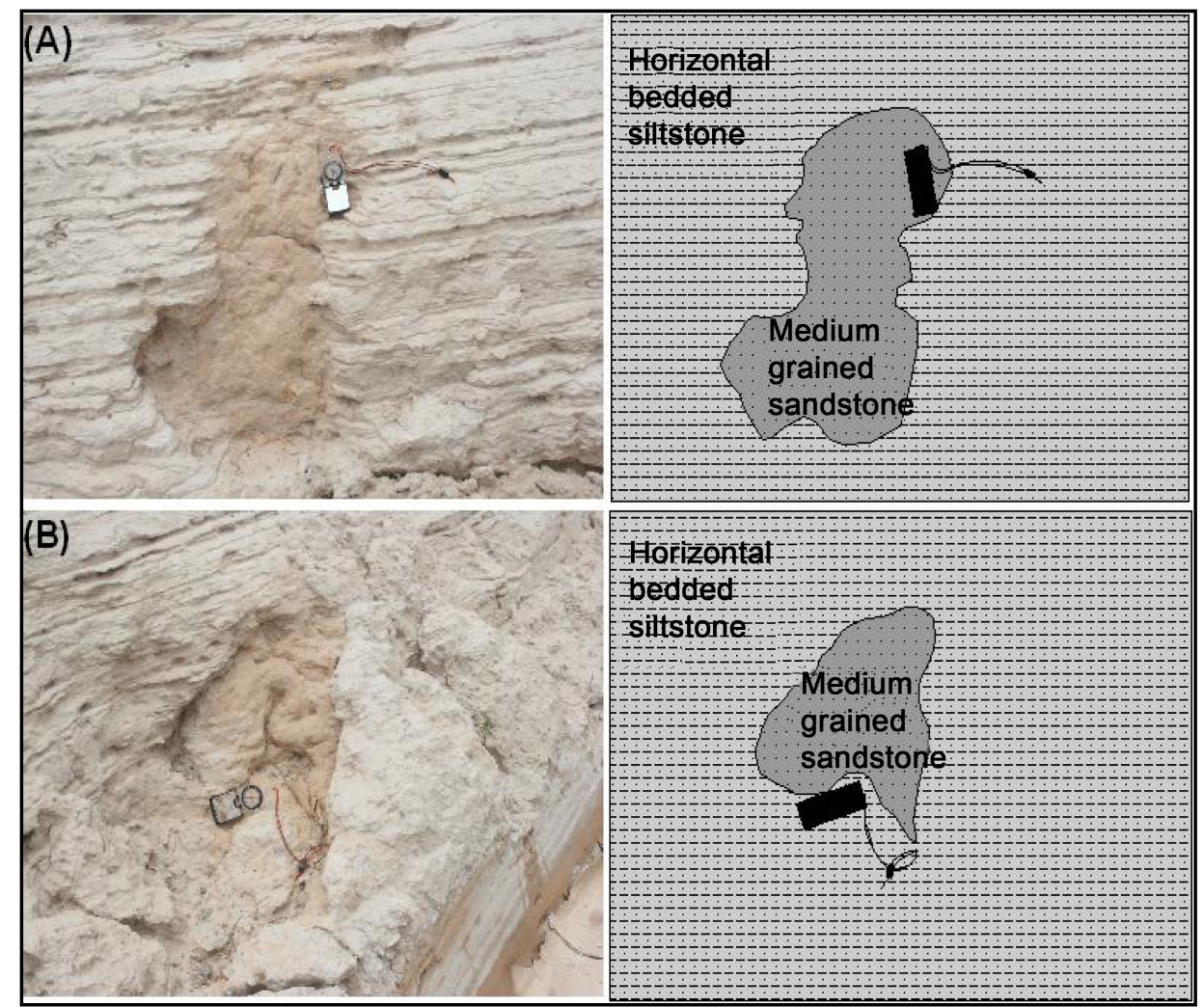

Figure 8. These figures show two types of thick clastic dykes recognised in the well laminated horizontal bedded heterolithic facies. Dykes are slightly inclined and have non-uniform thicknesses that vary from $20 \mathrm{~cm}$ to $30 \mathrm{~cm}$.

Figure 9(B)) load casts recognised in the area occur within a thin band (less than $3 \mathrm{~cm}$ thick) of well laminated and indurated very fine grained sandstone. These SSDS are generally massive and rarely preserve any structure except the SSD in Figure 9(B) where the internal laminations are contorted. The other type of load casts occurs within two lithologic boundaries. The upper lithology consists of unconsolidated fine to medium grained sandstone while the underlying lithology is a parallel bedded siltstone/clay (Figure 9(C)). These load casts are solitary and occur at various stratigraphic levels in association with tidal facies and do not occur with other SSDS.

2) Large Scale Load Structure

This structure was recognised only in one locality where it occurs in association with a channel fill (Figure 9(D)). Its length and height are approximately $9 \mathrm{~m}$ and $3 \mathrm{~m}$ respectively. Large scale load cast affects regular sandstone, siltstone and clay that underlie the channel and show a regular concave up morphology. Internal laminations are not well preserved because the infills are composed of clay and debris flow deposits. The lithology below shows a regular variation in thickness and bend gradually downwards from the margin of the channel towards the centre, thus increasing the inclination along same direction.

3) Sagging Load Structure

Well defined sagging load structure was identified in a sandstone unit that is $1.2 \mathrm{~m}$ thick (Figure 9). The structure is characterised by a convex downward morphology arranged into lobes. Each lobe is separated by distances that vary from $1.2 \mathrm{~cm}$ to $5.1 \mathrm{~cm}$. The size of individual lobes is between $1.5 \mathrm{~cm}$ and $13 \mathrm{~cm}$. The lithology containing the structure is separated from medium to coarse grained sandstone lithologies below and above by distinct sharp boundaries. Zone with sagging load structure occur in isolation as observed in the exposure. However, approximately $25 \mathrm{~m}$ away in the extension of the same outcrop ball structures occur. [32] define dish structures as thin, flat to concave-upward, argillaceous laminations in siltstone that are commonly accompanied by vertical or nearly vertical crosscutting columns and sheets of massive silt which are referred to as pillars. Similar structures (dish-pillar) were observed in the area of study in one location.

Interpretation: In this deformed layers the load casts originated in response to gravitational instabilities 
caused by unstable density gradient which allowed denser sediment to sink into less dense sediment. This process is related to liquefaction and drastic reduction in shear strength of the sediments [37]-[40] and [41]. Rapid sedimentation [42] and kinematic viscosity have been attributed as the controlling factors between the size and shape of load structures [43] [44]. Since these load casts are solitary and simple, it is reasonable to argue that the lithologies above and below the load casts have approximately equal viscosities. Also, rapid sedimentation may cause the loading of overlying lithologies into the lower ones before they are lithified [7] [42]. This phenomenon can also be responsible for the load casts that are recognised in the area

Driving Force Interpretation: Sediments in these deformed layers were probably subjected to post-depositional dewatering and gradual compaction from overlying rapidly deposited sediments. Fluidization process could have played some significant roles during the process of deformation. [4] have given similar interpretation to dish-and-pillar structures.

\subsubsection{Convolute Lamination}

Severely and moderately contorted laminations with varying degrees of deformation occur in the heteroliths facies of Patti Formation. They occur as folded layers with irregular morphologies of highly distorted stratification (Figures 10(A)-(C)). Usually the packages consist of siltstone lithology characterized by sharp upper and lower boundaries within clay and silt lithologies. Contorted laminations are found together with load structures, in one example, the load itself are composed of contorted materials (Figure 10(B)). In other outcrops, minor sediment loading was observed at the lower part of contorted laminations, although they occur in subtle manner. The disorganization was recognized in several outcrop sections that run through kilometers. The thicknesses of deformed layers vary from $6 \mathrm{~cm}$ to $15 \mathrm{~cm}$. Similar soft sediment deformation structures have been recognized in different types of deposits varying from continental to marine [2].

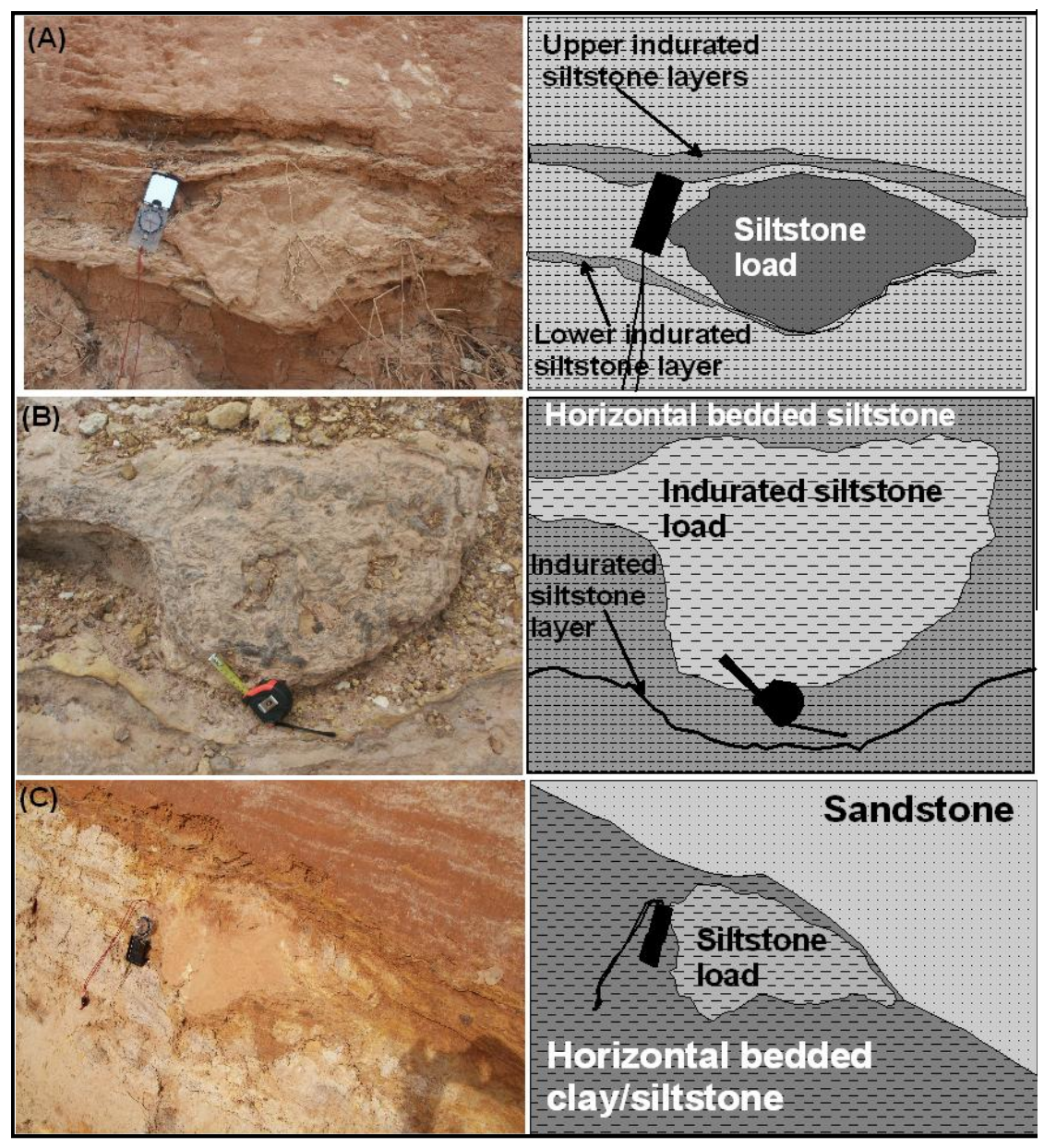



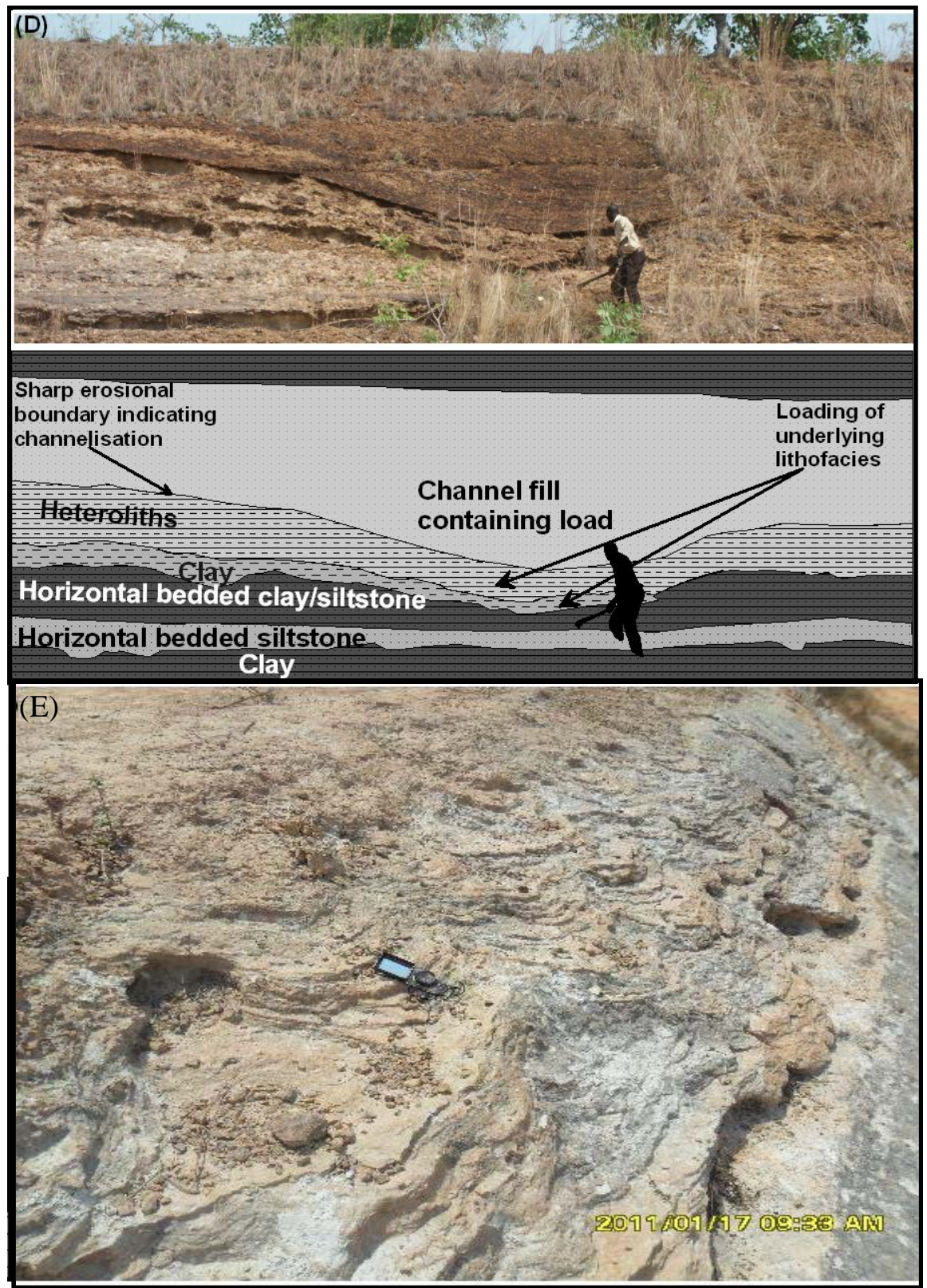

Figure 9. Load structures recognised in the area of study. (A) The upper and lower boundaries of the load structure contain indurated siltstone layers. Load is made up of unconsolidated loose silt. (B) Only the lower boundary of the load structure contains indurated siltstone. The load itself is made up of indurated siltstone. The structure preserved contorted internal laminations. (C) Formation of load structure at the boundary between two different lithologies. (D) Load structure formed as result of channel infill. Depression took place in two different lithologies underlying the channel while the third lithology was not affected. (E) Dish and pillar structures occurring within two lithologies.

Driving Force Interpretation: In the present case study, the contorted morphologies of the convolutions appear to indicate the action of pressure release during spontaneous liquefaction. Evidence of minor loading was observed in the lower part of the contorted laminations. Current forces and pressure release during spontaneous liquefaction have been recognised as factors responsible for the formation of convolute lamination [39] [45] [46]. Actions of normal sediment current forces were not apparent in the studied outcrops, since there was no evidence of dragging or other current features. 


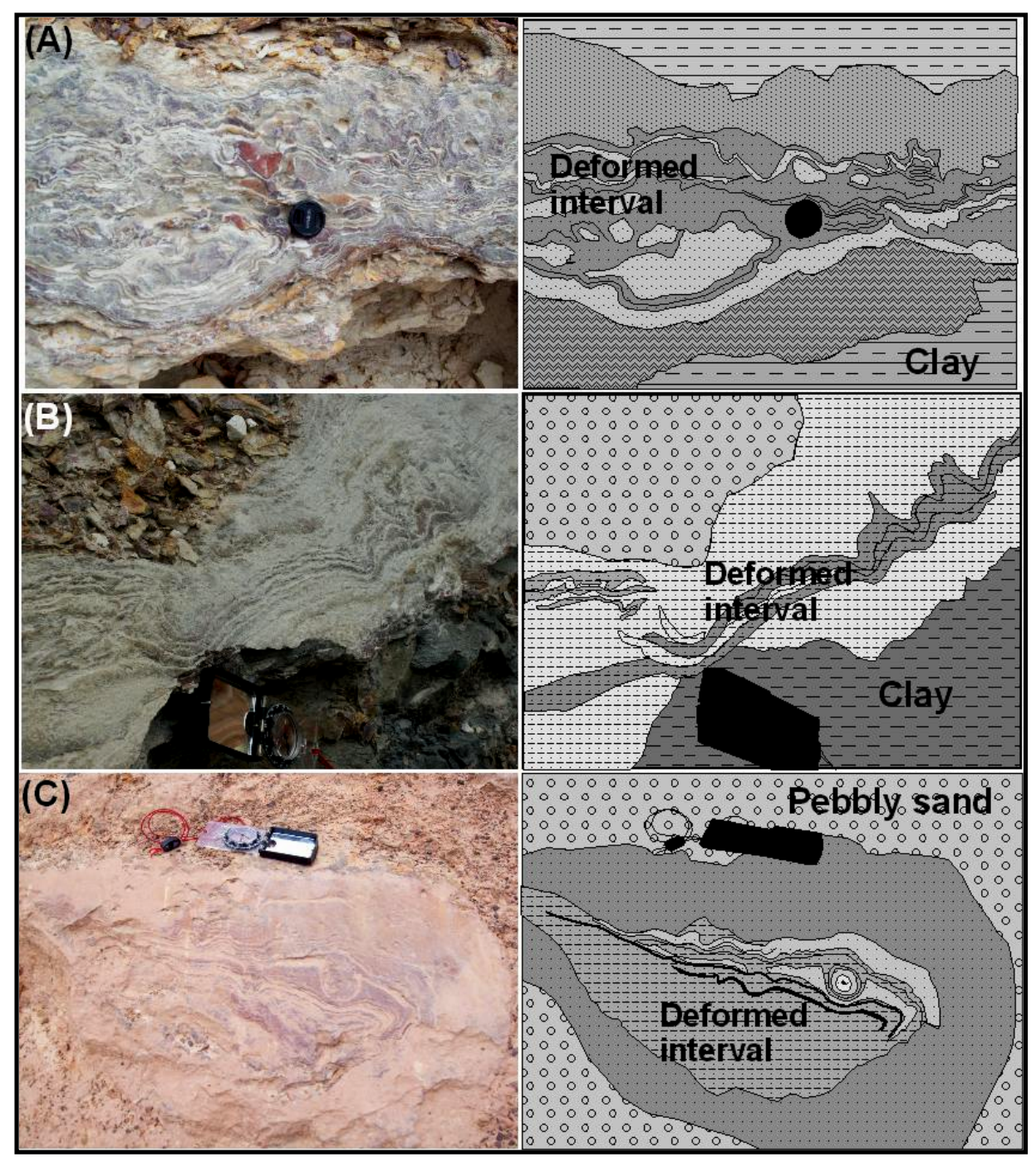

Figure 10. Convolute laminations identified in different localities in the area of study. (A) and (B) Distorted intervals are restricted to single stratigraphic layer with sharp upper and lower boundaries. (C) Deformed structure was recognised in a boulder surrounded by pebbly materials. These sediments suggest reworked sediments formed by debris deposits.

\subsubsection{Diapiric Structure}

Diapirs consist of intruded bodies resulting from the upward displacement of the overlying sediments. Two of such diapirs were identified in one location in the area of study (Figure 11). They occur as short, curved protuberances with wide base and slightly narrow upwards but exhibit different heights and widths. The base and the height of the longer one are about $5.5 \mathrm{~cm}$ and $8.2 \mathrm{~cm}$ respectively. The shorter diapir exhibits different morphology as the base has higher value than the height. Measured values for the base and the height are $5.2 \mathrm{~cm}$ and $3.1 \mathrm{~cm}$ respectively. Few lines occur at the base of the diapiric structures.

Driving Force Interpretation: Diapirs delineated in the study area are formed in response to interstitial water overpressure forcing the underlying sediments into the strata above. The fluidized sediments therefore formed the diapiric structures. Lines that were observed at the base of the diapiric structures can be related to upward flow of the sediments.

\subsubsection{Deformed Cross Beddings, Recumbent Folds, Crumpled and Slightly Deformed Beds}

1) Deformed Cross Beddings

This structure consists of severely deformed cross beddings which have caused the development of crumpling, 
convolutions and elongated structures (Figure 12(A)). This was identified in one exposure in Gadabiu locality. This structure is restricted to a small part of the exposure; it is composed of alternating layer of coarse grained
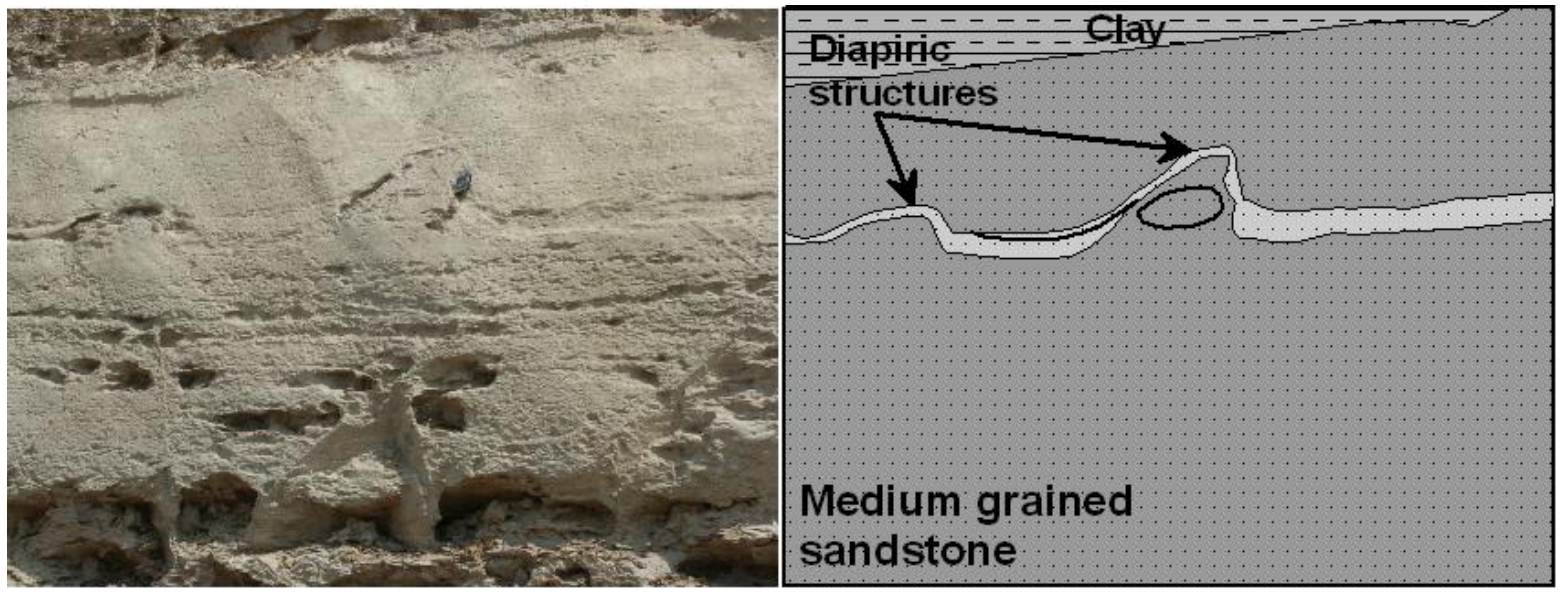

Figure 11. Occurrence of diapiric structures in the area of study. Two different types was recognised in the exposed sandstone bed. Diapirs are made up very thin siltstone that intruded into the overlying sediment.

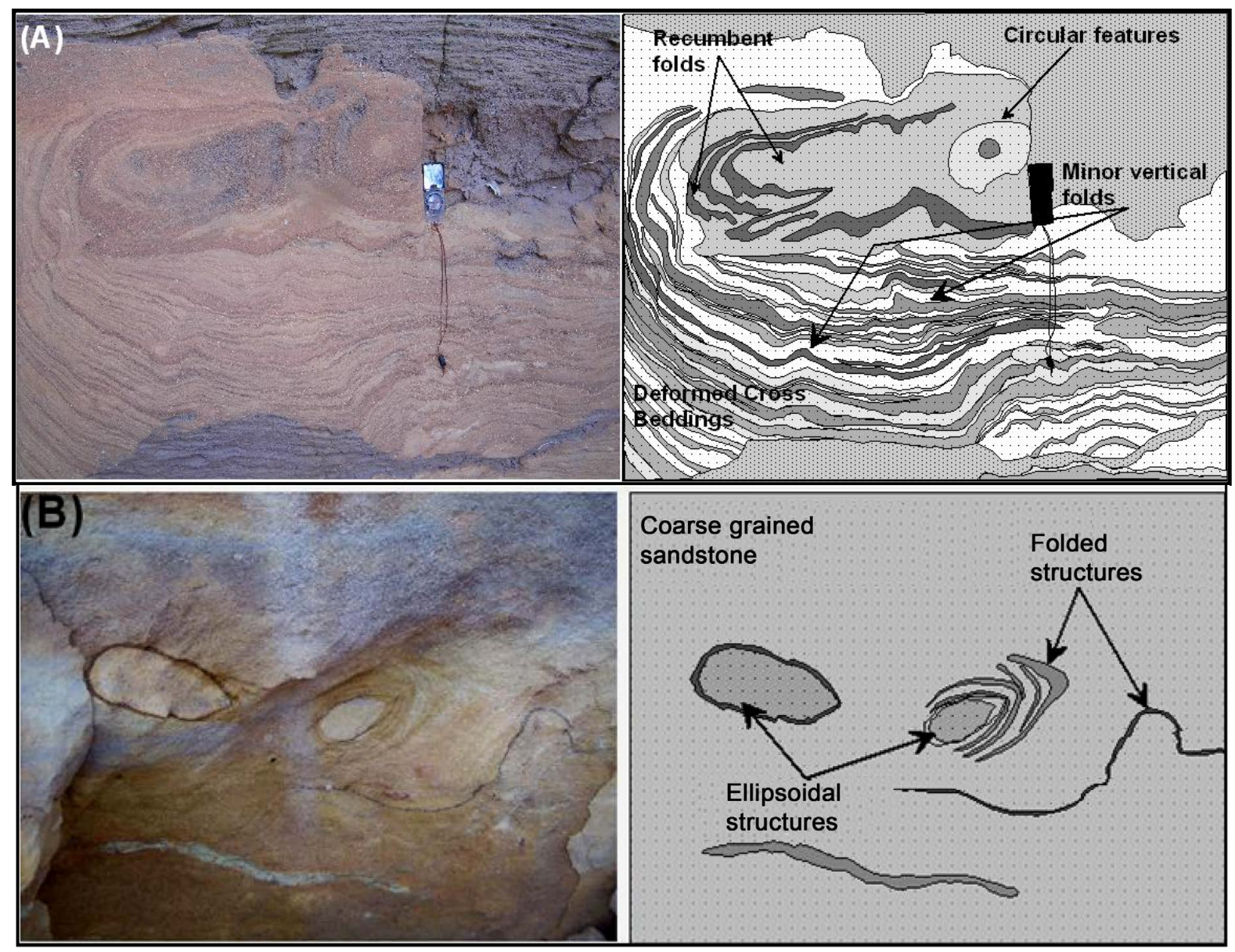

Figure 12. Severely deformed cross beddings in association with other SSDS such as recumbent folds, minor folds and circular to sub-circular structures. (A) Planar cross beds have been deformed into different types of folds (recumbent, minor) and circular structures. (B) Ellipsoidal structures in association recumbent and normal folds. These SSDS was identified in fluvial sediments. 
uniform sand. The deformed section is up to $1.7 \mathrm{~m}$ thick where recumbent folds, contorted bedding, ball and elongated structures can be found co-existing (Figure 12(A)).

The section consists of well defined cross beds with overturned internal stratification, which form recumbent folds with near horizontal axial planes. These recumbent folds are characterized by slightly irregular, isoclinal limbs. In the upper part the folded layer pinches out, while in the lower part the folded layer is continuous. As observed in the exposed section, vertical measurement of fold limbs reveals that the lower limb is thicker than upper limb having thicknesses of $1.3 \mathrm{~m}$ and $40 \mathrm{~cm}$ respectively. Other deformation features such minor folds are present. The degree of deformation is restricted to a particular section of the exposure and become less pronounced vertically and laterally in both directions, as the deformation disappear into the cross beds.

2) Recumbent folds, Crumpled and Slightly Deformed Beds

This structure consists of crumpling or convolutions identified in some exposures. These structures are restricted to the small part of the studied sections. In the tidal sediments the recumbent fold is composed of alternating layer of fine grained sand and siltstone exhibiting uniform colour. It consists of cross beds with overturned internal stratification, which form recumbent folds with near horizontal axial planes. These recumbent folds are regular, isoclinal and face each other (Figure 13(A)). The folded layer pinches out in a few tens of centimetres at both ends and characterised by sharp top and gradational lower part. Vertical measurement of fold limbs reveal that they are generally less than $25 \mathrm{~cm}$ in thickness. The degree of deformation becomes less pronounced laterally in both directions, as the folds diffuse into the cross beds. Recumbent folds were also identified in the fluvial sediments, but in these cases they are associated with other SSDS (Figure 12(B)). Crumpled beds are also restricted to small part of the studied sections. These beds are roughened and inclined at angles that
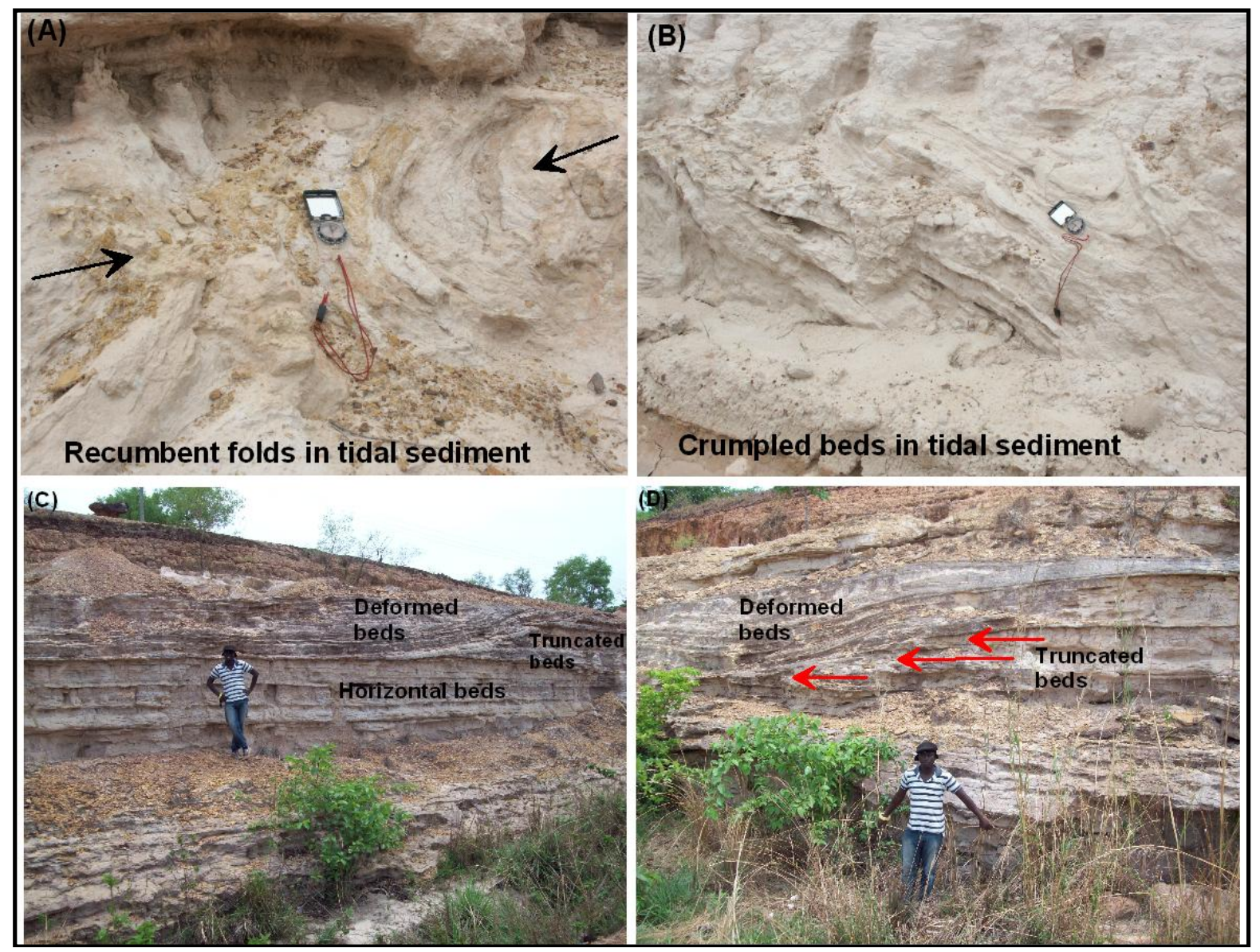

Figure 13. Recumbent folds, crumpled and slightly deformed beds in tidal sediments. The black arrows in A are pointing to the direction of folds. In B the crumpled beds are inclined at angle that vary from $35^{\circ}$ to $47^{\circ}$. (C) and (D) show slightly deformed and truncated beds caused by tidal erosion. The red arrows point to the direction of truncation. 
vary between $35^{\circ}$ and $47^{\circ}$ (Figure 13(B)).

Driving Force Interpretation: The formation of recumbent folds and deformed cross beds have been attributed to factors such as autokinetic processes related to liquefaction [47]-[49] and allokinetic occurrence such as earthquake [50]. [30] interpreted similar recumbent folds as to have developed under hydroplastic behaviour in a quasi-solid state. The coherence of the recumbent folds identified in the tidal sediments without other deformations is an indication that laminar flow probably deformed the primary bedding [2]. In the fluvial sediments, other deformations were in association with the recumbent folds and the limbs stratification was deformed suggesting that turbulent flow deformed the primary bedding. The formation of the recumbent folds and other deformations as observed probably occurred after noticeable reduction in the shear strength of the sediments. These folds reflect ductile deforming process and the structures associated with them can be interpreted as evidence of fluidization and liquefaction, occurring at the same time with the formation of the folds. The recumbently folded cross beds are produced by liquefaction either during the deposition of the sediments or during post-depositional processes before final lithification of the sediments. The morphologies of the recumbent folds recognised in the area of study are similar to other recumbent folds that have been described from different types of sedimentary basins and sedimentary environments [49] [51] [52].

\subsubsection{Sand Balls and Pseudonodules}

Two types of ball structures were identified in the area of study; 1) isolated, and 2) associated ball structures (Figure 12, Figure 14 and Figure 15). Isolated ball structures are made up of sand characterised by sub-circular to circular shape, in some cases the outside layers are irregular. The sediments surrounding the structure may or may not be of similar lithology as the structure. Two categories of isolated ball structures identified are; 1) small, and 2) large structures. Small structures illustrated in Figure 14(A) and Figure 14(B) have diameters that vary from $6 \mathrm{~cm}$ to $22 \mathrm{~cm}$, they are reddish fine-medium grained sandstone bodies enclosed within tidally deposited, horizontal bedded grey siltstone. Large ball structures are characterised by large diameters that vary from $85 \mathrm{~cm}$ to $1.9 \mathrm{~m}$. They are purple-deep red, pebbly to gravelly sand bodies enclosed within light brown-red, mediumcoarse grained sandstone lithologies (Figure 14(C) and Figure 14(D)).

In addition to isolated ball structures identified in the studied sections, it was observed that at two locations in Gadabiu locality where fluvial sediments were recognised associated ball structures occurred. In the first section, recumbent folds, contorted lamination, ellipsoidal structures and other folded structures can be found co-existing. (Figure 12(B)). Ball structures in association with severely deformed cross beddings in the first location have diameters that vary from $3.5 \mathrm{~cm}$ to $7.5 \mathrm{~cm}$ and are composed of similar lithology. Associated ball structures in the second exposure at Gadabiu locality co-existed with minor recumbent folds, normal folds and other deformations. The structures have been deformed to ellipsoidal shapes with blunt and pointed sides (Figure 12(B)). The structures are surrounded by highly indurated siltstone layer about $0.5 \mathrm{~cm}$ thick. Measured dimensions of the structure vary from $3.5 \mathrm{~cm} \times 6.8 \mathrm{~cm}$ to $5.2 \mathrm{~cm} \times 12 \mathrm{~cm}$. The structures are essentially light grey with brown patches coarse grained sandstone bodies enclosed within coarse grained brown-dark grey sandstone bodies.

Pseudonodules are associated with the indurated siltstone unit and form layers that vary in thickness from 20 $\mathrm{cm}$ to $45 \mathrm{~cm}$. The structure is c arranged laterally into various shapes-rounded to subrounded, elongated and irregular. Pseudonodules are enclosed within indurated siltstone layer separated from other lithologies by upper and lower sharp boundaries containing discrete units. Other structures in association are pinch-and-swell, stretched and elongated lithologies. The centre parts of the pseudonodules are made up of hollows, which are recognised as fluid/water escape features (Figure 15).

Driving Force Interpretation: Ball structures have been regarded as structures formed in a reverse density gradient system caused by waves induced liquefaction [53]. The deformation usually develops before lithification in non-cohesive sediments by liquefaction and/or fluidization. These processes increase interstitial pressure within the sediment, even nullifying its shear strength, so that the sediment behaves as a viscous fluid [1]. When shear strength in the sediment decreases or disappears suddenly through liquefaction, a gravitational readjustment takes place at the interface between the two units. As a result, the denser upper unit collapses whereas a mixture of sediment from the lower unit and interstitial fluid intrudes simultaneously into the overlying layer (fluidization). The existence of a reversed density gradient (a coarser sand unit overlying a less coarse sand unit) in the sand facies from the area of study could act as a driving force system. It is apparent that all the isolated ball structures delineated in the study area were formed by this process, because the structures contain coarser 
lithologic units when compared with the surrounding facies. The sand balls and ellipsoidal bodies within the sediments were clearly derived from the descent of overlying sediments.
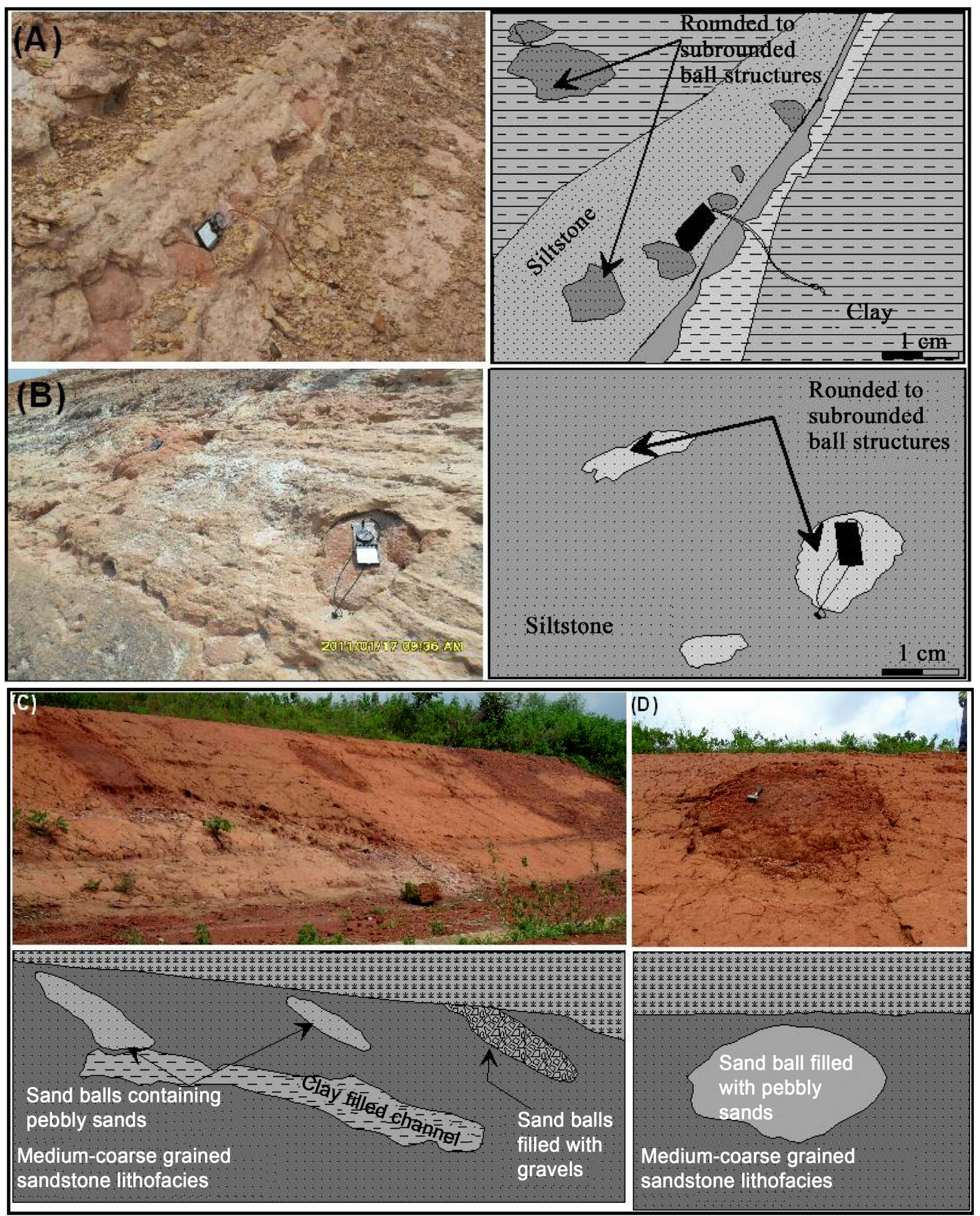

Figure 14. Field photographs showing the occurrence of ball structures. (A) and (B) are small ball structures recognised in the tidal sediments. (C) and (D) are large ball structures within fluvial sediments. Ball structures contain sediments that are coarser than surrounding lithology. 


\subsubsection{Ring Structure}

Ring structure was observed in one exposure located in Gadabiu, two of this structure was seen separately and they are not far away from each other within a distance of $20 \mathrm{~m}$. The first structure is well formed and most of the rings features can be easily identified while the second structure is subtle and the ring feature are not well defined. The structure is made up of sand characterised by concentric circular shape bodies arrange in beds (Figure 16). The sediments surrounding the structure may or may not be of similar lithology as the structure. Ring structure shown in Figure 16 has vertical and horizontal diameters of $1.2 \mathrm{~m}$ and $1.4 \mathrm{~m}$ respectively. It is composed of brownish very coarse grained sand body similar to the lithology enclosing it. The structure was identified in fluvial deposited sediments.

Driving Force Interpretation: The formation of ring structure can attributed to factors related to autokinetic processes such as liquefaction. The turning of the cross beds to ring structure is an indication that the original stratification was deformed. This suggests that turbulent flow could have deformed the primary bedding. The formation of the ring structure as observed probably occurred after noticeable reduction in the shear strength of the sediments. Absence of tilted and truncated part within the beds as well as the preservation of the original beddings of the ring structure clearly indicates that the structure was formed in a low or zero shear resistance situation induced by liquefaction. Morphological features of the ring deformation depend additionally on the ratio of dynamic viscosities of the liquefied sediment layers [43] [53] and the duration of the liquefied state [42].

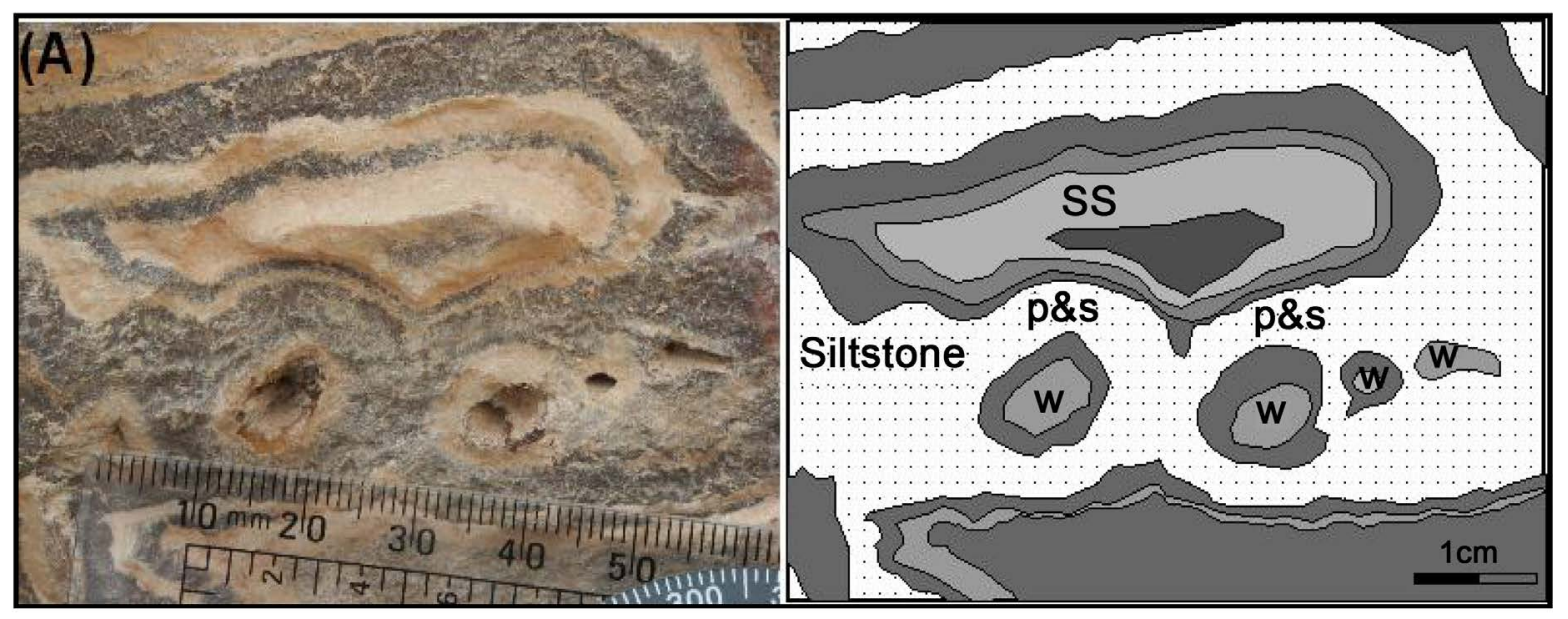

Figure 15. Field photo and line drawing of pseudonodule characterised by different structures such-water escape holes (w), pinch-and-swell (p\&s) and stretched lithologies (ss).

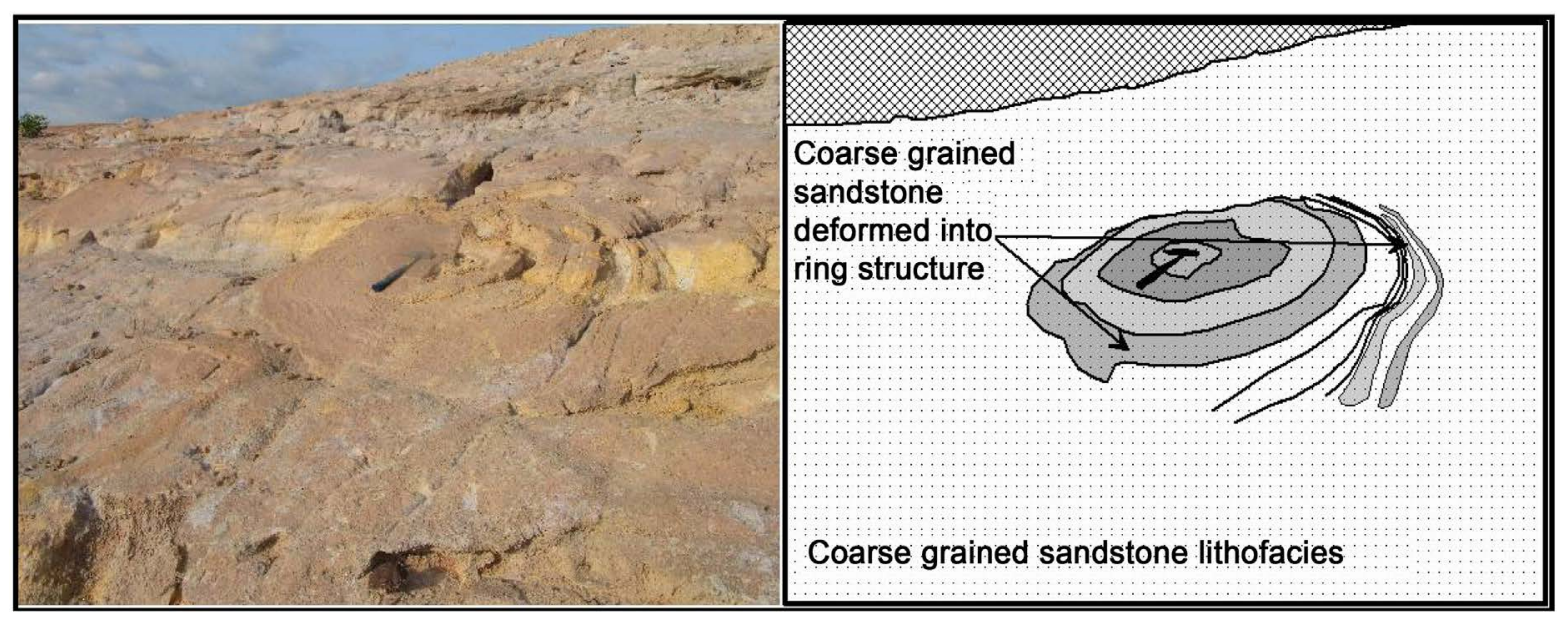

Figure 16. Field photo and line drawing of ring structure as identified in the fluvial sediment. Note that the structure contain concentric layers of coarse grained sandstone. 


\section{Discussion}

Sedimentary successions characterised by soft-sediment deformation structures occur within the Maastrichtian tidal and fluvial sediments in the Bida Basin. The deformed lithofacies occur at different lithofacies within the Patti formation (Figure 6). The quarries and several kilometers long of new exposures produced from road construction provide good means for studying of the exposures. The discussion aspect of this paper shall focus on the three stage process of [3] outlined for the identification of trigger agents for SSDS. The process is facies, trigger and criteria assessments.

\subsection{Facies Assessment and Paleo-Environmental Significance}

Field studies of the lithofacies reveal the occurrence of different types of primary structures which are closely related to two distinct types of depositional environments; tidal and fluvial. The occurrence of excellent exposures of heterolithic facies within the studied outcrops of the Patti Formation enabled the interpretation of tidal depositional environments. The heterolithic facies is charcterised by repetitive thickening and thinning of the lamination sets containing rippled structure, reactivation surfaces, mud couplets and erosional surfaces. As previously presented, occurrence of poorly sorted, coarse grained cross bedded sandstones characterised by different vertical successions (uniform graded, normal graded and inverse graded) within the Patti Formation can be well justified in the case of fluvial sedimentation. The observations in this study agree well with those of earlier interpretations by [10] [18] [20] [54]-[56]. These authors have discussed the prevailing tidal and fluvial facies successions within the Patti Formation in the Bida Basin.

As established in this study, the morphologies, occurrence and distribution of soft-sediment deformation structures (SSDS) within the Patti Formation show good uniformity within the different facies. Brittle deformation structure which occurred as thin clastic dykes are characteristic of shale, sandstone, laminated very fine sandstone and siltstone lithologies (Figures 6(D)-(F) and Figure 7) of the Patti Formation where such deformation occurs at different stratigraphical levels in different locations. These lithologic units were interpreted to have been deposited in non-marine, swamp overbank and tidal marsh/coastal swamp environments [10]. Another variety of the clastic dyke is found in fine grained heterolithic tidal deposits (Figure 8) of the Patti Formation where the deformation was confined to one stratigraphical level.

Clastic dykes identified in the studied area are laterally consistent and has wide distribution because it can be correlated for over $10 \mathrm{~km}$. However, these clastic dykes occur within sediments that were interpreted to be deposited in tidal marsh and coastal swamp environments [10]. Sediments deposited in tidal environment have high susceptibility to deformation because they are extremely sensitive to liquefaction. Depositional patterns in tidal settings favour loosely packed sand layers interbedded with clay layers (heterolithic facies). Clay layers have the potential to disperse excess pore pressures. Therefore, the tidal sediments identified in the Maastrichtian Patti Formation provide good basis for extensive liquefaction deformations to take place.

Small scale load casts and ball structures often display symmetrical to asymmetrical and irregular features, they are associated with boundary layers between two lithologies. These occurrences are clearly related to loading of the overlying sedimentary interface as a result of reversed density gradient system. In similar manner, the large scale load structure is also clearly related to interface between two different lithologies. In all of these cases the overlying material has sunk into the sediments below. In these deformations the lithofacies below are often characterized by alternation of beds of sandstone, siltstone and mudstone indicative of tidal deposits.

Different varieties of SSDS are found in the section interpreted as fluvial deposits in the area of study. Severely deformed cross beddings, ring structure and associated ball structures exhibit variation in sizes and morphologies. These soft-sediment deformation structures occur within thick-bedded and laterally stacked coarse grained sandstone lithofacies separated by mudstone (Figure 5 and Figure 12). In this facies SSDS were identified in two horizons at different stratigraphic levels. Severely deformed cross beddings occur at lower level while ring structure and associated ball structures occur at the upper stratigraphic level in the same sedimentary package but at different locations.

[7] has pointed out that there is a link between depositional environments of sediments and trigger of soft sediment deformation structures (SSDS). It can be affirmed that the distribution and occurrence of various SSDS at different stratigraphic levels within Patti Formation point to a link between the trigger agents for the deformation and depositional environments. Therefore, it can be inferred that the formation of the SSDS are due to endogenic triggers. In addition, some of the identified SSDS show genetic relationship to the primary sedimentary structures within the Patti Formation. The recumbent folds and crumpled beds within the tidal heterolithic facies 
(Figure 13) represents good example of deformation triggered by the current drag during the deposition of tidal sediments. Also, severely deformed cross beddings, ring structure and associated ball structures (Figure 12) in the fluvial sediments occur solitarily without lateral extension within same lithofacies. This occurrence refers to an endogenic rather than exogenic triggering mechanism.

\subsection{Trigger Assessment}

Some of the strong considerations used in interpreting SSDS caused by exogenic processes are large areal extent (covering many square kilometers), lateral consistency (correlatable in many outcrops) and vertical repetition [30] [35] [36] [57]-[59]. In this type of situation, the deformed layer is distinct and occurs between two undeformed layers at the top and below. SSDS caused by seismic activities (seismites) can often be identified and correlated over tens of kilometers and have huge lateral distribution [57]-[61]).

Soft-sediment deformations within the Patti Formation involve different sedimentary units with multiple events of liquefaction. Non-uniformity was observed in the occurrence of the soft-sediment deformation structures within the facies. In the exposures where the SSDS were identified, deformation types and morphologies did not vary vertically. Except in few outcrops where SSDS were observed at lower and upper stratigraphic levels, most SSDS were restricted to single stratigraphic interval. In the present study, layers containing SSDS did not provide individual good correlation and wide distribution. In many of the exposures soft sediment deformation structures can only be traced within few meters before they finally disappeared or thinned out and change to undeformed sediments in several cases. It was also observed that where soft sediment deformation structures appear in other exposures, they do not occur at the exact same stratigraphic level. These observations indicate triggering mechanisms not related to an external source (allogenic) for the development of the soft-sediment deformation structures [3]. Instead, autogenic triggering mechanisms are responsible for the soft sediment deformations.

On the basis of the depositional environments—shallow marine and fluvial, interpreted for the Patti Formation, which are usually characterise by high water energy the following triggering mechanisms are considered: 1) impact of breaking waves, 2) slumping/sliding on submarine slopes, 3) rapid sedimentation and overloading, 4) pressure fluctuations associated with turbulent water flow (tsunamis, tidal bores, floods, etc), 5) cyclic stress and current generated by storm waves, 6) changes in water level, and 7) biogenic activities resulting into bioturbation.

The deformations observed in the sediments were principally induced by liquefaction and/or fluidization processes in clay, shale, very fine-medium grained sandstones and coarse grained sandstones. The liquefaction and/or fluidization processes could be related to several autogenic natural trigger mechanisms as shown above. However, the actual origin of deformation structures identified on the field can be very difficult [7] [61] [62]. In order to identify the trigger mechanisms for the SSDS identified in the area of study, it is important to disregard some of the autogenic triggers mentioned above.

In the present study, sedimentary processes associated with slope failure such as gravity sliding, slumping and mass transport were not identified in the sedimentary successions, therefore, these processes can be disregarded [33]. Soft sediment deformations identified were in association with parallel beds having zero depositional dip. This implies that sedimentation must have taking place in extremely flat paleo-relief, therefore, spontaneous liquefaction on slopes between $22^{\circ}$ and $27^{\circ}$ is not likely to occur [59] [63]. Also, debris flow deposits and highly contorted beds usually associated with slope environment were not identified with the soft sediment deformations. In addition, faulting and slump folds which are indications of lateral stress were not observed within the lithofacies, hence slumping as one of the potential trigger can be excluded.

High rate of bioturbation caused by biogenic activities were not observed on the sediment surfaces. Large scale trace fossils caused by plant roots and footprints are absent in the deformations indicating that deformation triggered by such activities are not applicable in the present situation. The influence of tsunamis seems not rational for the type of soft sediment deformation structures delineated in the area of study. Tsunami deposits characterised by different sedimentological features were not identified within the lithofacies [64].

From the above, the reliable trigger mechanisms for the observed effects of liquefaction and fluidization in the studied sedimentary successions are 1) rapid sedimentation and overloading, 2) impact of breaking waves, 3) pressure fluctuations caused by turbulent water flow, and 4) cyclic stress and current generated by storm waves, 5) changes in water table. [65] have shown that rapid sedimentation is a very common trigger mechanism for liquefaction in several systems, which include sand-on-sand and sand-in-clay systems. Their calculations revealed that rapid deposition of sand could induce liquefaction at a considerable depth below the water-sediment inter- 
face and that excess pore water pressure can be maintained in the underlying sediments for many hours. Considering this fact it can be explained that the isolated sand balls and load structures are induced by rapid sedimentation and overloading. Load structures recognised in the area was interpreted as a product of unequal loading. Load structures are formed under depositional conditions that have low or zero shear resistance, which has the capability to induce liquefaction of sandy or silty sediments in reversed density gradient systems [1] [42] [61] [66].

Field experience revealed that the load casts recognised in the Maastrichtian Patti Formation show similarities with those formed in the laboratory work of [37] and those described by [2] and [53]. These load structures were interpreted as being formed in response to seismic activity. This submission does not conform with the load structures recognised in the present study, which do not have any resemblance to seismic origin because they do not meet the criteria for seismically induced SSDS as pointed out by [53] [67].

Rapid deposition of sediments in the channel (Figure 9) identified in the studied section could potentially be responsible for the loading of the underlying sediment layers. [62] have pointed out that SSDS in tidal flow deposits can be up to few tens of centimeters high. In the current study, the horizontally bedded tidal deposits are recumbently folded and disturbed (Figure 13), this indicates that the deposition from suspended sediments has been deformed as a result of pressure fluctuations caused by turbulent water flow or impact of breaking waves [61] [68].

Cyclic stress and current generated by storm are known to trigger deformation caused by liquefaction. These phenomena were observed in the present study, especially in the fluvial setting. Cyclic stress caused by storm waves has been reported as a liquefaction trigger in recent [69] and in ancient sedimentary environments [53] [70] [71]. In the present situation cyclic stress caused by fluvial currents are likely, because the deformation structures identified are genetically related to the fluvial deposits (severely deformed cross beddings, ring structures and associated ball structures with folds). It is inferred that cyclic stress caused by turbulent flow must have triggered these deformations.

[72] has related lowering of water level to ancient soft sediment deformation structures in shallow marine settings. In the fluvial sediments identified in the area of study, minor and major erosional features were identified during the deposition of the fluvial sediments in the Patti Formation. Deformed laminations were identified in one of the exposures, these laminations were truncated at the upper part indicating there was erosion caused by lowering of water level, hence their formation during lowering of water level is possible.

\subsection{Criteria Assessment}

In the area of study the most obvious soft sediment deformation structure is the brittle deformation occurring as clastic dykes, which was identified in two different locations within different lithologic units. In Ahoko the deformation occurs within sandstone and shale, whereas in Gerinya it occurs with clay and shale. Less obvious but still identified in many of the lithologies are ductile deformation structures such as load casts, ball structures and convolute laminations. Other ductile deformations that are rare and restricted to specific lithologies are recumbent folds, ring structure and severely deformed cross beddings. It is important to emphasize that earthquake triggered soft sediment deformation structures such sand volcanoes and thrust faults were not identified in the area of study.

Bida Basin constitutes one of the rift basins that originated during the Cretaceous and form part of Central and West Africa rift system. The origin of this system is related to the opening of the South Atlantic. Previous interpretations of remotely sensed data, geophysical data and borehole logs have suggested that the basin is bounded by a system of linear faults trending NW-SE [11] [20]. The basin sedimentary fills have been shown to be made up of post-orogenic molasse and thin unfolded marine sediments [73]. The origin of the basin is closely connected with Santonian orogenic movements, which affected several basins in Nigeria. The Bida Basin possibly remained tectonically quiescent after the Santonian tectonic pulse. This assertion strongly favors a non-tectonic origin for the SSDS that were identified in the area of study. These SSDS were observed in sediments deposited during the Maastrichtian. This indicates that the formation of SSDS in the basin post-date major tectonic event in the basin that can be related to earthquake.

Field observations, facies analysis and morphology of the soft sediment deformation structures in the Patti Formation show that: 1) deformation was induced by liquefaction and fluidization; 2) deformation occurs in tidal and fluvial sediments; 3 ) deformed structures are absent in the immediate overlying and underlying beds of the deformed layer, but may occur in other overlying lithologies (e.g. load casts and isolated ball structures occurred in same lithology, dish-and-pillar structure occurred in lithology above but not immediate); 4) similar 
deformed structures (e.g. clastic dykes) are not restricted to the same type of lithologies in different locations 5) layers containing SSDS are difficult to correlate laterally, and 6) vertical succession of deformed and undeformed beds are characterised by different lithologies. Beds containing SSDS in the area of study is not in conformity with originally reported seismite beds [59] [60] [74]-[76]. Therefore, earthquake shock seems not to be a feasible trigger factor for the formation of soft sediment deformation identified in the area.

From the above, the studied SSDS were formed along with the deposition of both tidal and fluvial sediments in agitated depositional conditions. Evidence of tidal (heterolithics, herringbone cross-stratification, reactivation surfaces, tidal bundles, tidal channels) and fluvial (poorly sorted gravelly sandstone, cross bedded sandstones characterised by different vertical successions-uniform, normal and inverse, channels deposits filled with mudstone and sandstones etc.) sedimentation are intimately related to the deformed beds. The SSDS associated with the tidal sediments such as load casts occur within lithologic boundaries, therefore, they are clearly related to loading from overlying layer triggered by storm-wave. Recumbent folds, slightly deformed and roughened horizontal beds are products of drag shear caused by tidal currents [77]. Deformed beds that are found within the cross beds of the fluvial sediments, which comprise severely deformed cross beds and ring structures (Figure 12 and Figure 16) are clearly related to agitated water conditions. In addition, careful observation of the sedimentary exposures revealed that lateral distribution of individual deformed beds in the exposures is restricted and confined, which points to autogenic origin.

\section{Conclusions}

This paper has focused on the recognition and description of soft sediment deformation structures (SSDS) in the tidal and fluvial sediments of Maastrichtian Patti Formation in the southern part of Bida Basin. Patti Formation is made up of facies associations which include; shoreface, tidal channel, tidal marsh-coastal swamp, fluvial channel, and non-marine/overbank. Lithofacies that are intimately related to tidal and fluvial deposits were recognised during fieldwork studies. Tidal sediments include heterolithic facies arranged in lamina/lamina sets and beds/bed sets; they are characterised by repetitive thickening and thinning upward lamination sets, rippled features, reactivation and erosional surfaces. Fluvial sediments are made up of uniformly coarse grained sandstone, inversely graded sandstone, normal graded cross bedded sandstone and mudstone. The vertical arrangements of these lithofacies are separated by mudstone and they exhibit different sedimentary structures.

Soft sediment deformation structures were recognised both in tidal and fluvial sedimentary successions, caused by effects of liquefaction and fluidization. Clastic dykes, load cast, sand balls, dish-and-pillar structures, convolute lamination, diapiric structures, recumbent folds and roughened beds are SSDS associated with tidal sediments. Severely deformed cross beds, ring structures, sand balls, normal folds and recumbent folds were identified in the fluvial sediments. Facies assessment/paleo-environmental significance, trigger assessment and criteria assessment were used to evaluate the most probable triggering mechanisms responsible for the formation of SSDS recognised in the Patti Formation.

Results obtained from this study indicate that there are clear linkages between the depositional environments and SSDS identified in them. For example clastic dykes, dish-and-pillar and load structures were restricted to different lithofacies units interpreted as tidal sediments, whereas severely deformed cross beds and ring structures were only identified in the fluvial sediments. Trigger assessment of the SSDS reveal that the deformations did not meet the criteria for exogenic processes as being responsible for the deformations. Instead the following endogenic processes were inferred as trigged mechanisms on the basis of depositional environments; rapid sedimentation and overloading, impact of breaking waves, pressure fluctuations caused by turbulent water flow, cyclic stress and current generated by storm waves and changes in water table. Criteria assessment of the soft sediment deformation structures reveals the occurrence of brittle and ductile deformations occurring at various degree of clarity in the following order: clastic dykes, load casts, ball structures, convolute laminations, recumbent folds, severely deformed cross beds, normal folds and roughened beds. Earthquake triggered soft sediment deformation structures such sand volcanoes and thrust faults were not identified in the sedimentary successions that were studied. Bida Basin has remained tectonically quiescent after the Santonian tectonic pulse, therefore the occurrence of SSDS in Maastrichtian sediments post-date major tectonic event in the basin that cannot be related to earthquake. The assertions made above strongly favor a non-tectonic origin for the SSDS. Field observations, facies analysis and morphology of the soft sediment deformation structures in the Patti Formation show a clear relationship between the identified SSDS and agitated water conditions of high energy dynamics in 
tidal and fluvial depositional environments.

\section{Acknowledgements}

The author is particularly grateful for the assistance he has received from everybody who has made the field works on SSDs huge success. I am also thankful to the anonymous reviewers, who have improved the quality of the manuscript tremendously.

\section{References}

[1] Allen, J.R.L. (1982) Developments in Sedimentology, Sedimentary Structures Their Character and Physical Basis Volume II. Volume 30, Part B, Elsevier, Amsterdam, 663 p.

[2] Moretti, M. and Sabato, L. (2007) Recognition of Trigger Mechanisms for Soft-Sediment Deformation in the Pleistocene Lacustrine Deposits of the Sant' Arcangelo Basin (Southern Italy): Seismic Shock vs. Overloading. Sedimentary Geology, 196, 31-45. http://dx.doi.org/10.1016/j.sedgeo.2006.05.012

[3] Owen, G., Moretti, M. and Alfaro, P. (2011) Recognising Triggers for Soft-Sediment Deformation: Current Understanding and Future Directions. Sedimentary Geology, 235, 133-140. http://dx.doi.org/10.1016/j.sedgeo.2010.12.010

[4] Lowe, D.R. (1975) Water Escape Structures in Coarse Grained Sediments. Sedimentology, 22, 157-204. http://dx.doi.org/10.1111/j.1365-3091.1975.tb00290.x

[5] Maltman, A. (1984) On the Term “Soft-Sediment Deformation”. Journal of Structural Geology, 6, 589-592. http://dx.doi.org/10.1016/0191-8141(84)90069-5

[6] Van Loon, A.J. (2002) Soft-Sediment Deformations in the Kleszczow Graben (Central Poland). Sedimentary Geology, 147, 57-70. http://dx.doi.org/10.1016/S0037-0738(01)00187-7

[7] Owen, G. and Moretti, M. (2011) Identifying Triggers for Liquefaction-Induced Soft Sediment Deformation in Sands. Sedimentary Geology, 235, 141-147. http://dx.doi.org/10.1016/j.sedgeo.2010.10.003

[8] Braide, S.P. (1992) Geological Development, Origin and Energy Mineral Resources Potential of the Lokoja Formation in the Southern Bida Basin. Journal of Mining and Geology, 28, 33-44.

[9] Akande, S.O., Ojo, O.J., Erdtmann, B.D. and Hetenyi, M. (2005) Paleoenvironments, Organic Petrology and Rock Eval Studies on Source Rock Facies of the Campanian to Maastrichtian Patti Formation, Southern Bida Basin, Nigeria. Sedimentary Geology, 41, 394-406. http://dx.doi.org/10.1016/j.jafrearsci.2005.07.006

[10] Ojo, O.J. and Akande, S.O. (2009) Sedimentology and Depositional Environments of the Maastrichtian Patti Formation, Southeastern Bida Basin, Nigeria. Cretaceous Research, 30, 1415-1425. http://dx.doi.org/10.1016/j.cretres.2009.08.006

[11] Ojo, S.B. and Ajakaiye, D.E. (1989) Preliminary Interpretation of Gravity Measurements in the Middle Niger Basin Area, Nigeria. In: Kogbe, C.A., Ed., Geology of Nigeria, 2nd Edition, Elizabethan Publishing Company, Lagos, 347358.

[12] Udensi, E.E. and Osazuwa, I.B. (2004) Spectra Determination of Depths to Magnetic Rocks under the Nupe Basin, Nigeria. Nigerian Association of Petroleum Explorationists Bulletin, 17, 22-37.

[13] Whiteman, A. (1982) Nigeria: Its Petroleum Geology, Resources and Potential. Vol. 1 and 2, Graham and Trotman, London, 349 p. http://dx.doi.org/10.1007/978-94-009-7361-9

[14] Falconer, J.D. (1911) The Geology and Geography of Northern Nigeria. Macmillan, London, 255p.

[15] Russ, W. (1930) The Minna-Birnin Gwarri Belt. Reports of the Geological Survey of Nigeria, 10-14.

[16] Jones, H.A. (1958) The Oolitic Ironstone of Agbaja Plateau, Kabba Province. Record of the Geological Survey of Nigeria, 20-43.

[17] Du Chene, J., Adegoke, O.S. and Adediran, S.A. (1978) Palynology and Foraminifera of the Lokoja Sandstone (Maastrichtian), Bida Basin, Nigeria. Revista Espanola De Micropaleontologia, 10, 379-393

[18] Ladipo, O., Akande, S.O. and Mucke, A. (1994) Genesis of Ironstones from Middle Niger Sedimentary Basin, Evidence from Sedimentological, Ore Microscopic and Geochemical Studies. Journal of Mining and Geology, 30, 161- 168.

[19] Olaniyan, O. and Olobaniyi, S.B. (1996) Facies Analysis of the Bida Sandstone Formation around Kajita, Nupe Basin, Nigeria. Sedimentary Geology, 23, 253-256. http://dx.doi.org/10.1016/S0899-5362(96)00066-8

[20] Ojo, O.J. and Akande, S.O. (2003) Facies Relationships and Depositional Environments of the Upper Cretaceous Lokoja Formation in the Bida Basin, Nigeria. Journal of Mining and Geology, 39, 39-48. http://dx.doi.org/10.4314/jmg.v39i1.18789

[21] Miall, A.D. (1992) Alluvial Models. In: Walker, R.G. and James, N.P., Eds., Facies Models Response to Sea Level Change, Geological Association of Canada, St. John's, 119-142. 
[22] El-Azabi, M.H. and El-Araby, A. (2005) Depositional Facies, Environments and Sequence Stratigraphic Interpretation of the Middle Triassic-Lower Cretaceous (Pre-Late Albian) Succession in Arif El-Naga Anticline, Northeast Sinai, Egypt. Sedimentary Geology, 41, 119-143. http://dx.doi.org/10.1016/j.jafrearsci.2005.02.005

[23] Miall, A.D. (1985) Architectural-Element Analysis: A New Method of Facies Analysis Applied to Fluvial Deposits. Earth-Science Reviews, 22, 261-308. http://dx.doi.org/10.1016/0012-8252(85)90001-7

[24] Miall, A.D. (1978) Lithofacies Types and Vertical Profile Models in Braided River Deposits: A Summary. In: Miall, A.D., Ed., Fluvial Sedimentology, Memoir 5, Canadian Society of Petroleum Geologists, Calgary, 597-604.

[25] Cappuzo, N. and Wetzel, A. (2004) Facies and Basin Architecture of the Late Carboniferous Salvan-Dore'naz Continental Basin (Western Alps, Switzerland/France). Sedimentology, 51, 675-697. http://dx.doi.org/10.1111/j.1365-3091.2004.00642.x

[26] Roberts, E.M. (2007) Facies Architecture and Depositional Environments of the Upper Cretaceous Kaiparowits Formation, Southern Utah. Sedimentary Geology, 197, 207-233. http://dx.doi.org/10.1016/j.sedgeo.2006.10.001

[27] Montenat, C., Barrier, P., Ott d’Estevou, P. and Hibsch, C. (2007) Seismites: An Attempt at Critical Analysis and Classification. Sedimentary Geology, 196, 5-30. http://dx.doi.org/10.1016/j.sedgeo.2006.08.004

[28] Berra, F. and Felletti, F. (2011) Syndepositional Tectonics Recorded by Soft-Sediment Deformation and Liquefaction Structures (Continental Lower Permian Sediments, Southern Alps, Northern Italy): Stratigraphic Significance. Sedimentary Geology, 235, 249-263. http://dx.doi.org/10.1016/j.sedgeo.2010.08.006

[29] Montenat, C., Ott D’Estevou, P. and Masse, P. (1987) Tectonic-Sedimentary Characters of the Betic Neogene Basins Evolving in a Crustal Transcurrent Shear Zone (SE Spain). Bulletin Du Centre De Recherches Elf Exploration Production, 11, 1-22.

[30] Martín-Chivelet, J., Palma, R.M., López-Gómez, J. and Kietzmann, D.A. (2011) Earthquake-Induced Soft-Sediment Deformation Structures in Upper Jurassic Open-Marine Microbialites (Neuquén Basin, Argentina). Sedimentary Geology, 235, 210-221. http://dx.doi.org/10.1016/j.sedgeo.2010.09.017

[31] Ezquerro, L., Moretti, M., Liesa, C.L., Luzón, A. and Simón, J.L. (2015) Seismites from a Well Core of Palustrine Deposits as a Tool for Reconstructing the Palaeoseismic History of a Fault. Tectonophysics, 655, 191-205. http://dx.doi.org/10.1016/j.tecto.2015.05.025

[32] Lowe, D.R. and LoPiccolo, L.D. (1975) The Characteristics and Origins of Dish and Pillar Structures. Journal of Sedimentary Petrology, 44, 484-501.

[33] Ghosh, S.K., Pandey, A.K., Prabha Pandey, P., Ray, Y. and Sinha, S. (2012) Soft-Sediment Deformation Structures from the Paleoproterozoic Damtha Group of Garhwal Lesser Himalaya, India. Sedimentary Geology, 261-262, 76-89. http://dx.doi.org/10.1016/j.sedgeo.2012.03.006

[34] Rijsdijk, K.F. (2001) Density-Driven Deformation Structures in Glycogenic Consolidated Dialects: Examples from Traethy y Mwnt, Cardiganshire, Wales, UK. Journal of Sedimentary Research, 71, 122-135. http://dx.doi.org/10.1306/042900710122

[35] Obermeier, S.F. (1996) Use of Liquefaction-Induced Features for Paleo Seismic Analysis-An Overview of How Seismic Liquefaction Features Can Be Distinguished from Other Features and How Their Origin Can Be Used to Infer the Location and Strength of Holocene Paleo-Earthquakes. Engineering Geology, 44, 1-76. http://dx.doi.org/10.1016/S0013-7952(96)00040-3

[36] Obermeier, S.F. (1998) Liquefaction Evidence for Strong Earthquakes of Holocene and Latest Pleistocene Ages in the States of Indiana and Illinois, USA. Engineering Geology, 50, 227-254. http://dx.doi.org/10.1016/S0013-7952(98)00032-5

[37] Moretti, M., Alfaro, P., Caselles, O. and Canas, J.A. (1999) Modelling Seismites with a Digital Shaking Table. Tectonophysics, 304, 369-383. http://dx.doi.org/10.1016/S0040-1951(98)00289-3

[38] Koc, Tasgin, C. (2011) Seismically-Generated Hydroplastic Deformation Structures in the Late Miocene Lacustrine Deposits of the Malatya Basin, Eastern Turkey. Sedimentary Geology, 235, 264-276. http://dx.doi.org/10.1016/j.sedgeo.2010.09.015

[39] Suter, F., Martinez, J.I. and Velez, M.I. (2011) Holocene Soft-Sediment Deformation of the Santa Fe Sopetran Basin, Northern Colombian Andes: Evidence for Pre-Hispanic Seismic Activity. Sedimentary Geology, 235, 188-199. http://dx.doi.org/10.1016/j.sedgeo.2010.09.018

[40] He, B., Qiao, X., Jiao, C., Xu, Z., Cai, Z., Guo, X. and Zhang, Y. (2014) Palaeo-Earthquake Events during the Late Early Palaeozoic in the Central Tarim Basin (NW China): Evidence from Deep Drilling Cores. Geologos, 20, 105-123. http://dx.doi.org/10.2478/logos-2014-0006

[41] He, B., Qiao, X., Zhang, Y., Tian, H., Cai, Z., Chen., S. and Zhang, Y. (2015) Soft-Sediment Deformation Structures in the Cretaceous Zhucheng Depression, Shandong Province, East China, Their Character, Deformation Timing and Tectonic Implications. Journal of Asian Earth Sciences, 110, 101-122. http://dx.doi.org/10.1016/j.jseaes.2014.12.005 
[42] Owen, G. (2003) Load Structures: Gravity-Driven Sediment Mobilization in the Shallow Subsurface. In: Van Rensbergen, P., Hillis, R.R., Maltman, A.J. and Morley, C.K., Eds., Subsurface Sediment Mobilization, Special Publications, London, Vol. 216, 21-34. http://dx.doi.org/10.1144/gsl.sp.2003.216.01.03

[43] Anketell, J.M., Cegla, J. and Dzulynski, S. (1970) On the Deformational Structures in Systems with Reversed Density Gradients. Annales de la Société Géologique de Pologne, 15, 3-29.

[44] Mills, P.C. (1983) Genesis and Diagnostic Value of Soft-Sediment Deformation Structures-A Review. Sedimentary Geology, 35, 83-104. http://dx.doi.org/10.1016/0037-0738(83)90046-5

[45] Sanders, J.E. (1960) Origin of Convoluted Laminae. Geological Magazine, 97, 409-421. http://dx.doi.org/10.1017/S0016756800061768

[46] Dzulynski, S. and Smith, A.J. (1963) Convolute Lamination, Its Origin, Preservation and Directional Significance. Journal of Sedimentary Petrology, 33, 616-627.

[47] Allen, J.R.L. and Banks, N.L. (1972) An Interpretation and Analysis of Recumbent Folded Deformed cross Bedding. Sedimentology, 19, 257-283. http://dx.doi.org/10.1111/j.1365-3091.1972.tb00024.x

[48] Røe, S.L. and Hermansen, M. (2006) New Aspects of Deformed Cross-Strata in Fluvial Sandstones: Examples from Neoproterozoic Formations in Northern Norway. Sedimentary Geology, 186, 283-293. http://dx.doi.org/10.1016/j.sedgeo.2005.11.023

[49] Røe, S.L. and Hermansen, M. (2007) New Aspects of Deformed Cross-Strata in Fluvial Sandstone: Examples from Neoproterozoic Formations in Northern Norway-Reply. Sedimentary Geology, 198, 355-358. http://dx.doi.org/10.1016/j.sedgeo.2006.11.005

[50] Mazumder, R., van Loon, A.J. and Arima, M. (2006) Soft-Sediment Deformation Structures in the Earth's Oldest Seismites. Sedimentary Geology, 186, 19-26. http://dx.doi.org/10.1016/j.sedgeo.2005.12.002

[51] Tasgın, C.K., Orhan, H., Türkmen, I. and Aksoy, E. (2011) Soft-Sediment Deformation Structures in the Late Miocene S_Elmo Formation around Adiyaman Area, Southeastern Turkey. Sedimentary Geology, 235, 277-291. http://dx.doi.org/10.1016/j.sedgeo.2010.08.005

[52] Olabode, S.O. (2013) Soft Sediment Deformation Structures in the Maastrichtian Ajali Formation Western Flank of Anambra Basin, Southern Nigeria. Sedimentary Geology, 89, 16-30. http://dx.doi.org/10.1016/j.jafrearsci.2013.09.006

[53] Alfaro, P., Delgado, J., Estévez, A., Molina, J.M., Moretti, M. and Soria, J.M. (2002) Liquefaction and Fluidization Structures in Messinian Storm Deposits (Bajo Segura Basin, Betic Cordillera, Southern Spain). International Journal of Earth Sciences, 91, 505-513. http://dx.doi.org/10.1007/s00531-001-0241-z

[54] Agyingi, C.M. (1993) Palynological Evidence for a Late Cretaceous Age for Patti Formation, Eastern Bida Basin, Nigeria. Sedimentary Geology, 17, 513-523. http://dx.doi.org/10.1016/0899-5362(93)90008-E

[55] Abimbola, A.F., Badejoko, T.A., Elueze, A.A. and Akande, S.O. (1999) The Agbaja Ironstone Formation, Nupe Basin, Nigeria. A Product of Replacement of a Kaolinite Precursor. Global Journal of Pure and Applied Sciences, 5, 375-384.

[56] Ojo, O.J. and Akande, S.O. (2008) Microfloral Assemblage and Palaeoenvironment of the Upper Cretaceous Patti Formation, Southeastern Bida Basin, Nigeria. Journal of Mining and Geology, 44, 71-81. http://dx.doi.org/10.4314/jmg.v44i1.18885

[57] Galli, P. (2000) New Empirical Relationships between Magnitude and Distance for Liquefaction. Tectonophysics, 324, 169-187. http://dx.doi.org/10.1016/S0040-1951(00)00118-9

[58] Simms, M.J. (2007) Uniquely Extensive Soft-Sediment Deformation in the Rhaetian of the UK: Evidence for Earthquake or Impact? Palaeogeography, Palaeoclimatology, Palaeoecology, 244, 407-423. http://dx.doi.org/10.1016/j.palaeo.2006.06.037

[59] Põldsaar, K. and Ainsaar, L. (2014) Extensive Soft-Sediment Deformation Structures in the Early Darriwilian (Middle Ordovician) Shallow Marine Siliciclastic Sediments formed on the Baltoscandian Carbonate Ramp, Northwestern Estonia. Marine Geology, 356, 111-127. http://dx.doi.org/10.1016/j.margeo.2013.08.012

[60] Jewell, H.E. and Ettensohn, F.R. (2004) An Ancient Seismite Response to Taconianfar-Field Forces: The Cane Run Bed, Upper Ordovician (Trenton) Lexington Limestone, Central Kentucky (USA). Journal of Geodynamics, 37, 487-511. http://dx.doi.org/10.1016/j.jog.2004.02.017

[61] Põldsaar, K. and Ainsaar, L. (2015) Soft-Sediment Deformation Structures in the Cambrian (Series 2) Tidal Deposits (NW Estonia): Implications for Identifying Endogenic Triggering Mechanisms in Ancient Sedimentary Record. Palaeoworld, 24, 16-35. http://dx.doi.org/10.1016/j.palwor.2014.12.003

[62] Greb, S.F. and Archer, A.W. (2007) Soft-Sediment Deformation Produced by Tides in a Meizoseismic Area, Turnagain Arm, Alaska. The Geological Society of America, 35, 435-438. http://dx.doi.org/10.1130/g23209a.1

[63] Chaney, R.C. and Fang, H.Y. (1991) Liquefaction in the Coastal Environment: An Analysis and Case Histories. Marine Geotechnology, 10, 343-370. http://dx.doi.org/10.1080/10641199109379899 
[64] Alsop, G.I. and Marco, S. (2012) Tsunami and Seiche-Triggered Deformation within Offshore Sediments. Sedimentary Geology, 261-262, 90-107. http://dx.doi.org/10.1016/j.sedgeo.2012.03.013

[65] Moretti, M., Soria, J.M., Alfaro, P. and Walsh, N. (2001) Asymmetrical Soft-Sediment Deformation Structures Triggered by Rapid Sedimentation in Turbiditic Deposits. Facies, 44, 283-294. http://dx.doi.org/10.1007/BF02668179

[66] Alfaro, P., Moretti, M. and Soria, J.M. (1997) Soft-Sediment Deformation Structures Induced by Earthquakes (Seismites) in Pliocene Lacustrine Deposits (Guadix-Baza Basin, Central Betic Cordillera). Eclogae Geologicae Helvetiae, 90, 531-540.

[67] Jones, A.P. and Omoto, K. (2000) Towards Establishing Criteria for Identifying Trigger Mechanisms for Soft-Sediment Deformation: Case Study of Late Pleistocene Lacustrine Sands and Clays, Onokobe and Nakayamadaira Basins, Northeastern Japan. Sedimentology, 47, 1211-1226. http://dx.doi.org/10.1046/j.1365-3091.2000.00355.x

[68] Dalrymple, R.W. (1979) Wave-Induced Liquefaction: A Modern Example from the Bay of Fundy. Sedimentology, 26, 835-844. http://dx.doi.org/10.1111/j.1365-3091.1979.tb00976.x

[69] Foda, A.M., Hunt, J.R. and Chou, H.T. (1993) A Nonlinear Model for the Fluidization of Marine Mud by Waves. Journal of Geophysics Research, 98, 7039-7047. http://dx.doi.org/10.1029/92JC02797

[70] Monila, J.M., Alfaro, P., Moretti, M. and Soria, J.M. (1998) Soft-Sediment Deformation Structures Induced by Cyclic Stress of Storm Waves in Tempesites (Miocene, Guadalquivir Basin, Spain). Terra Nova, 10, 145-150. http://dx.doi.org/10.1046/j.1365-3121.1998.00183.x

[71] Chen, J.T. and Lee, H.S. (2013) Soft-Sediment Deformation Structures in Cambrian Siliciclastic and Carbonate Storm Deposits (Shandong Province, China): Differential Liquefaction and Fluidization Triggered by Storm-Wave Loading. Sedimentary Geology, 288, 81-94. http://dx.doi.org/10.1016/j.sedgeo.2013.02.001

[72] Chen, J.T., Chough, S.K., Han, Z.Z. and Lee, J.H. (2011) An Extensive Erosion Surface of a Strongly Deformed Limestone Bed in the Gushan and Chaomidian Formations (Late Middle Cambrian to Furongian), Shandong Province, China: Sequence-Stratigraphic Implications. Sedimentary Geology, 233, 129-149. http://dx.doi.org/10.1016/j.sedgeo.2010.11.002

[73] Obaje, N.G., Balogu, D.O., Idris-Nda, A., Goro, I.A., Ibrahim, S.I., Musa, M.K., Dantata, S.H., Yusuf, I., Mamud-Dadi, N. and Kolo, I.A. (2013) Preliminary Integrated Hydrocarbon Prospectivity Evaluation of the Bida Basin in North Central Nigeria. Petroleum. Technology Development Journal, 3, 36-65.

[74] Seilacher, A. (1969) Fault-Grade Beds Interpreted as Seismites. Sedimentology, 13, 155-159. http://dx.doi.org/10.1111/j.1365-3091.1969.tb01125.x

[75] Obermeier, S.F., Olson, S.M. and Green, R.A. (2005) Field Occurrences of Liquefaction-Induced Features: A Primer for Engineering Geo-Logic Analysis of Paleoseismic Shaking. Engineering Geology, 76, 209-234. http://dx.doi.org/10.1016/j.enggeo.2004.07.009

[76] Gibert, L., Alfaro, P., Garcia-Tortosa, F.J. and Scott, G. (2011) Superposed Deformed Beds Produced by Single Earthquakes (Tecopa Basin, California): Insights into Paleoseismology. Sedimentary Geology, 235, 148-159. http://dx.doi.org/10.1016/j.sedgeo.2010.08.003

[77] Battacharya, H.N. and Battacharya, B. (2010) Soft-Sediment Deformation Structures an Ice-Marginal Storm-Tide Interactive System, Permo-Carboniferous Talchir Formation, Talchir Coal Basin, India. Sedimentary Geology, 223, 380-389. http://dx.doi.org/10.1016/j.sedgeo.2009.12.002

\title{
Submit or recommend next manuscript to SCIRP and we will provide best service for you:
}

\author{
Accepting pre-submission inquiries through Email, Facebook, Linkedin, Twitter, etc \\ A wide selection of journals (inclusive of 9 subjects, more than 200 journals) \\ Providing a 24-hour high-quality service \\ User-friendly online submission system \\ Fair and swift peer-review system \\ Efficient typesetting and proofreading procedure \\ Display of the result of downloads and visits, as well as the number of cited articles \\ Maximum dissemination of your research work
}

Submit your manuscript at: http://papersubmission.scirp.org/ 